\title{
Paleoproterozoic Domo of Lava from Iriri Group - Sonho Meu Farm - Northeast of Mato Grosso, Amazon Craton: geology, geochemistry, and geochronology
}

\author{
Mara Luiza Barros Pita Rocha ${ }^{1}$, Márcia Aparecida de Sant'Ana Barros ${ }^{1 *}$, \\ Evandro Fernandes de Lima ${ }^{2}$ Ronaldo Pierosan ${ }^{3}$
}

\begin{abstract}
The Iriri Group is composed of acid to intermediate effusive and pyroclastic rocks, which crop out in Northeastern Mato Grosso state, Western Vila Rica. In the vicinity of Sonho Meu Farm, there is some part of an acid to intermediate lava dome, which is $2 \mathrm{~km}$ long and $250 \mathrm{~m}$ wide. The dome has a hypabyssal core that changes laterally to an autoclastic facies rich in pumice and shards with mingling textures, and subsequently to a facies with flow structures. The core has porphyritic texture and phenocrysts of plagioclase and biotite embedded in a medium-grained matrix of the same composition. The pumice-rich facies has a texture similar to ignimbrites and reoignimbrites. In this facies, a porphyritic to glomeroporphyritic texture is observed, with evidence of pumice collapse. The magma mixture is characterized by clusters of hornblende and plagioclase, in the form of millimetric to decimetric enclaves. Geochemical data on the rocks with no evidence of mingling indicate metaluminous to peraluminous high-K calcalkaline compositions. Rare earth elements patterns show a slight enrichment in LREE over HREE. Geochemical data show an enrichment in $\mathrm{Rb}, \mathrm{Sr}$, and $\mathrm{K}_{2} \mathrm{O}$ and a negative $\mathrm{Ta}-\mathrm{Nb}$ anomaly, which is common in calcalkaline rocks. Concentrations of trace elements are compatible with post-collisional tectonic environments. U-Pb zircon geochronology yields an age of $1.87 \mathrm{Ga}$. Sm-Nd isotopic studies report negative $€ \mathrm{Nd}$ values and Archean $\mathrm{Nd}$ model ages, indicating contamination by crustal material. This paper suggested that such dome was formed by melting of the lithospheric mantle, modified by previous subduction events, with subsequent magmatic differentiation.
\end{abstract}

Keywords: Iriri Group; dome; Amazonian Craton; magma mixture; postcollisional.

Resumo Domo de Lava Paleoproterozoico do Grupo Iriri-Fazenda Sonho Meu-Nordeste de Mato Grosso: geologia, geoquímica e geocronologia. O Grupo Iriri é composto de rochas ácidas a intermediárias efusivas e piroclásticas, as quais afloram no Nordeste de Mato Grosso, Oeste de Vila Rica. Nos arredores da Fazenda Sonho Meu, há uma parte de um domo de lava ácido a intermediário, com $2 \mathrm{~km}$ de comprimento e $250 \mathrm{~m}$ de largura $\mathrm{O}$ domo tem um núcleo hipoabissal que muda lateralmente para fácies autoclástica rica em púmice e shards com feições texturais de mistura e, subsequentemente, para uma com estrutura de fluxo. O núcleo tem textura porfirítica com fenocristais de plagioclásio e biotia imersos numa matriz de mesma composição. A fácies rica em púmice tem textura similar a ignimbritos e reoignimbritos. Nesta fácies, textura porfirítica à glomeroporfirítica é observada, com evidência de colapso de púmice. A mistura de magma é caracterizada por clusters de hornblenda e plagioclásio na forma de enclaves milimétricos a decimétricos. Dados geoquímicos nas rochas sem evidências de misturas variam de metaluminosas a peraluminosas e apresentam composição cálcio-alcalina a alto potássio. Os padrões de elementos terras raras exibem um leve enriquecimento de leves sobre pesados. Dados geoquímicos mostram enriquecimento em $\mathrm{Rb}, \mathrm{Sr}$ e $\mathrm{K}_{2} \mathrm{O}$ e anomalia negativa de $\mathrm{Ta}-\mathrm{Nb}$, que são comuns em rochas cálcio-alcalina. Concentrações de elementos traços são compatíveis com um ambiente tectônico pós-colisional. Dados geocronológicos U-Pb em zircão mostram uma idade de 1,87 Ga. Dados isotópicos de Sm-Nd relatam valores negativos de $€ \mathrm{Nd}$ e idades modelos $\mathrm{Nd}$ arqueanas, indicando contaminação por material crustal. Este trabalho sugeriu que tal domo foi formado por fusão de manto litosférico modificado por evento de subducção prévia, com subsequente processo de diferenciação magmática.

Palavras-chave: Grupo Iriri; domo; cráton Amazônico; mistura de magma; pós-colisional.

\section{INTRODUCTION Until recently, the volcan-} ic rocks of Uatumã Supergroup, which overlies the Amazon Craton, were called by several names depending on their geographical location. In the Guiana Shield (Northern Amazonian Craton), these rocks were named Iricoumé and Surumu Groups, whereas, in the Guaporé Shield (Southern of the craton), they were named as Iriri and Roosevelt Groups and
Sobreiro Formation (Barros et al. 2008). These rocks were formed by a large-scale taphrogenesis, which marked the breakup of a Paleoproterozoic supercontinent (Amaral 1974, Basei 1977). After new geological mapping techniques were developed, detailed geochemical and geochronological studies were carried out in different parts of the Amazonian Craton and the theory of geotectonic evolution by accreted

\footnotetext{
${ }^{1}$ Universidade Federal do Mato Grosso - UFMT, Cuiabá (MT), Brasil. E-mail: marapita1@yahoo.com.br; mapabarros@yahoo.com ${ }^{2}$ Universidade Federal do Rio Grande do Sul - UFRGS, Porto Alegre (RS), Brasil. E-mail: evandro.lima@ufrgs.br ${ }^{3}$ Departamento de Recursos Minerais da UFMT, Cuiabá (MT), Brasil. E-mail: ronaldo.pierosan@yahoo.com.br *Corresponding author
} 
arcs was proposed by Tassinari \& Macambira (1999), the stratigraphy of the Uatumã Supergroup needed to be re-examined (Dall'Agnol et al. 1987, 1994, 1999). In the Mato Grosso state, from the Western to the Northeastern part of the Amazonian Craton, these rocks were named Iriri Formation and later Iriri Group.

Leite et al. (2001) included the volcanic rocks located in Northern Mato Grosso, in a large igneous province (LIP) and called them Teles Pires Volcanic Province. Pinho et al. (2003), based on U-Pb isotopic dating of zircons $(1.77-1.80 \mathrm{Ga})$ and TDM values $(2.1$ $\mathrm{Ga})$ obtained from volcanic rocks with bimodal characteristics of the Moriru region, adopted the same nomenclature. Lacerda Filho (2004) called the andesitic and rhyolitic volcanic rocks from the Colíder and Matupá regions, which are included in the LIP defined by Leite et al. (2001), as Colíder Formation. Due to the type section of the Iriri Group be located in the Pará state and has a crystallization age of $1.88 \mathrm{Ga}$ and an Archean model age (Santos et al. 2000) indicated that further studies were necessary to separate Iriri volcanic rocks from other felsic magmatism present at Amazon Craton.

Preliminary U-Pb data and $143 \mathrm{Nd} / 144 \mathrm{Nd}$ isotope ratios obtained from pyroclastic rocks of Northeastern Mato Grosso, by Pinho et al. (2004), Padilha (2007) and Barros et al. (2009), showed values similar to those of the Iriri Group rocks, according to Santos et al. (2000). Thus, they have been correlated with the Iricoumé Group, which is overlies the Guiana Shield. Both the Iriri and the Iricoumé Groups are related to Orosirian volcano-plutonic events. The
Mapuera granite is the plutonic representative of the Iricoumé Group and the Maloquinha and Rio Dourado granites are representatives of the Iriri Group.

The mean goal of this study was to characterize the Paleoproterozoic volcanism (1.88 to 1.87 $\mathrm{Ga}$ ) of the Iriri Group, especially the Lava Dome of Sonho Meu Farm, which is located in Northeastern Mato Grosso state (Fig. 1). Although more information were obtained on this region over the last years, there is a lack of detailed geological, geochemical, and isotopic data, as well as accurate data on this volcanic association in the Amazon Craton as a whole.

ANALYTICAL METHODS Chemical analyses of 14 representative samples of this dome were carried out in the Acme Analytical Laboratories LTD, Vancouver, in Canada. Major elements were analyzed according to methods related to the Inductively Coupled Plasma - Emission Spectrometry (ICP-ES) for major elements and the ICP-MS (mass spectrometry) for trace elements.

Geochronological studies involved dating 13 zircon crystals using the Laser Ablation (LA) ICP-MS $\mathrm{U}-\mathrm{Pb}$ method. $\mathrm{U}-\mathrm{Pb}$ isotopic compositions were measured using a Laser Ablation Microprobe (New Wave UP-213) coupled to a Multicollector-Inductively Coupled Plasma Mass Spectrometer (MC-ICPMS) (Neptune), which has nine Faraday-type collectors and six electron multiplier channels. The equipment sample holder is made of nylon and is designed to carry three mounts, one sample and two geological standards, the

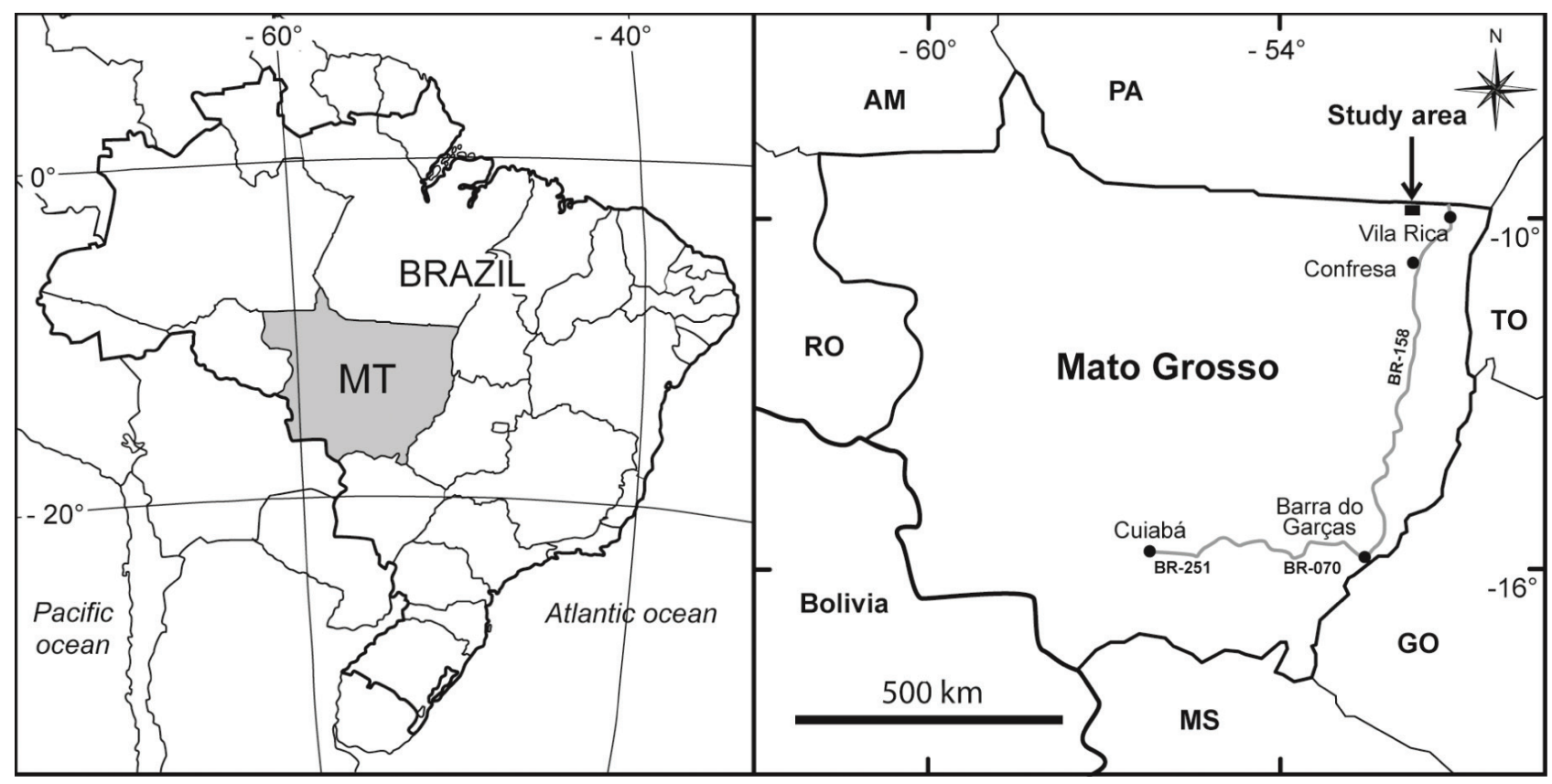

Figure 1 -Location map of the study area and access roads. 
GJ-1 (Jackson et al. 2004) and the internal standard. The analyses were carried out at the Geochronology Laboratory of the University of Brasília (UnB). Sm-Nd whole rock analyses were performed in the same laboratory with two samples of volcanic rocks. $€ \mathrm{Nd}$ values were calculated based on the U-Pb age obtained for the rhyolite sample (PT-251), which was described by Barros et al. (2006). Nd and Sm were extracted using conventional procedures of ionic exchange described by Patchett \& Ruiz (1987). Nd and Sm were analyzed using the Finnigan MAT-262 mass spectrometer with seven collectors. Backscattered electron (BSE) images of the zircons in mount were obtained in the laboratory of the Emílio Goeldi Museum, in Belém, using a scanning transmission electron microscope.

\section{GEOLOGICAL-GEOTECTONIC CONTEXT}

Evolution of the Amazon Craton, which is formed by the Guiana and Guaporé Shields that are separated by the Solimões and Amazonas basins, is related to a mobilistic model that produced an Archean block
(Carajás), where magmatic arcs were accreted from 2.3 to $1.0 \mathrm{Ga}$. Tassinari \& Macambira $(1999,2004)$ (Fig. 2A) and Santos et al. (2000, 2006) (Fig. 2B) discussed the province limits and names. The study area is located in Southern Amazonian Craton, in the Central Amazonian Province defined by Tassinari \& Macambira (2004) - Xingú-Iricoumé Block.

The study area is located within the Southern part of the Central Amazonian province, which is characterized by high-K calcalkaline volcano-plutonic associations, calcalkaline granites produced in arc environments (Vila Rica Intrusive Suite), A-type granites (Rio Dourado Intrusive Suite), basic-ultrabasic associations (Santa Inês Intrusive Suite), and mafic dikes. Sedimentary covers were found to occur in small amounts.

REGIONAL GEOLOGY Fig. 3 shows the geological map of the study area. According to Alves et al. (2010), Northeastern Mato Grosso is formed by Santana do Araguaia Complex towards East, which is cut by Vila Rica Intrusive Suite, and

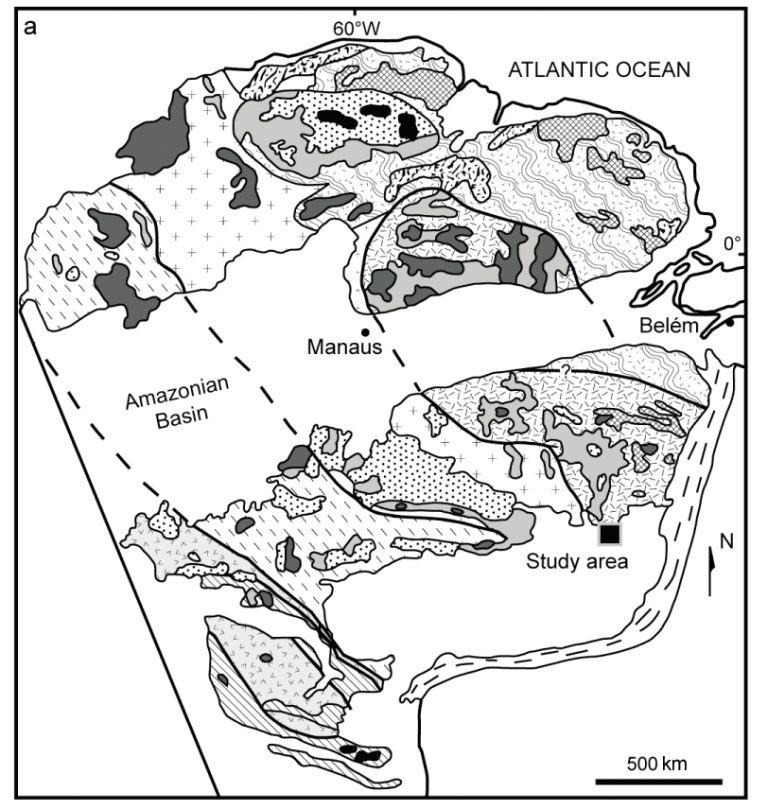

Caption

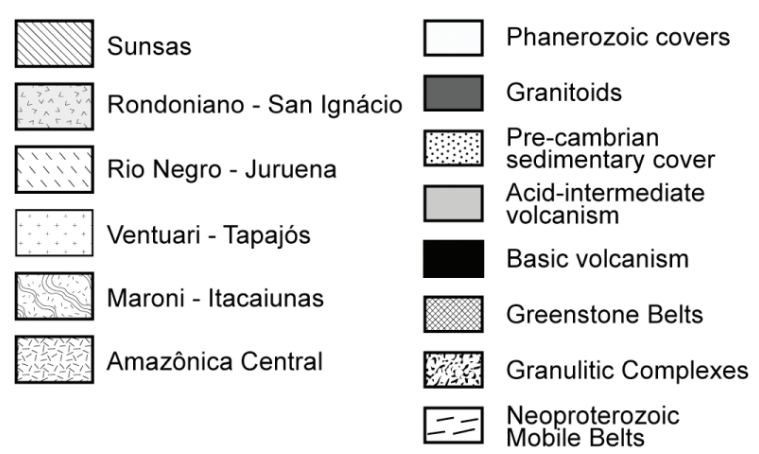

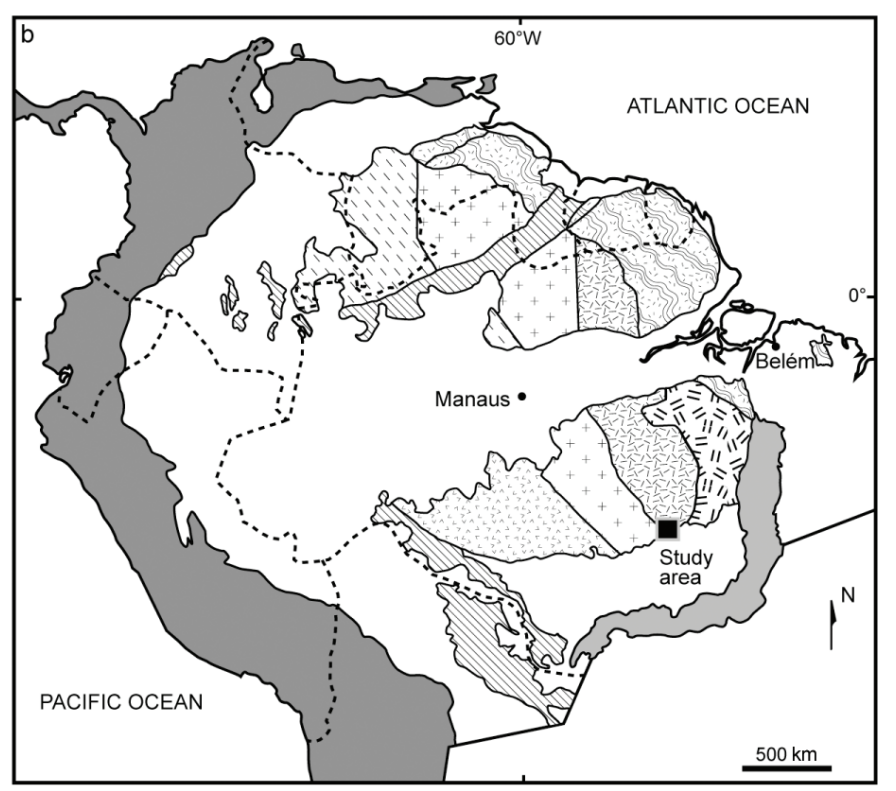

Caption

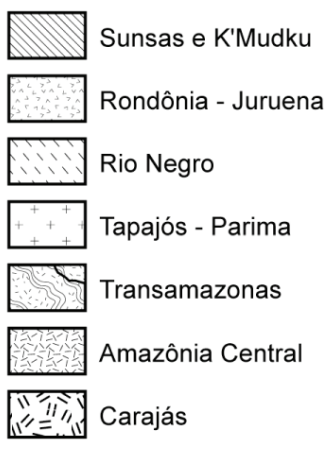

$\because$ International borders

Figure 2-Maps of the geotectonic-geochronological models of the Amazon Craton proposed by: (A) Tassinari \& Macambira (1999, 2004) and (B) Santos et al. (2000, 2006), showing the localization of the study area. 
Rio Dourado Intrusive Suite towards West. In Vila Rica Intrusive Suite, monzogranites are dominant, in addition to granodiorite and diorite, which show high-K calcalkaline affinity and were formed during the final development phase of the Tapajós-Parima or Ventuari-Tapajós arcs (Padilha \& Barros, 2008). The granitoids of this suite, which were dated using $\mathrm{U}-\mathrm{Pb}$ method on zircons at $1.96 \mathrm{Ga}$ (Padilha \& Barros 2008, Barros et al. 2009), are polydeformed and composed of orthogneisses (Fig. 4A) with isotopic signatures suggesting participation of the Archean continental crust.

Rio Dourado Intrusive Suite (Fig. 4B) was described by Padilha \& Barros (2008) and Barros et al. $(2009,2011)$ as an A-type granite suite of postdepositional environments, with $\mathrm{U}-\mathrm{Pb}$ age of $1.88 \mathrm{Ga}$. Rio Dourado Intrusive Suite has been interpreted as a plutonic part of the Iriri magmatism, in the same way the Mapuera Intrusive Suite has been interpreted as a plutonic part of the Iricoumé Group.

In the study area, Iriri Group volcanic rocks were represented by an association of rhyolites, dacites, andesites, and trachyandesites (Fig. 4C). Pyroclastic breccias with fragments ranging from millimeters to $30 \mathrm{~cm}$ were locally observed (Fig. 4D).

Gabbroic intrusions with stratiform structures, formed by hornblende and olivine gabbro (Fig. 4E), called Santa Inês Intrusive Suite (Barros et al. 2011), also occured associated with granites. Sensitive High-Resolution Ion Microprobe (SHRIMP) U-Pb data indicated an age close to that of the Iriri Group $(1.87 \mathrm{Ga})$ for the Santa Inês Intrusive Suite. Diabase dikes (Fig. 4F) of tholeitic composition and undetermined age cut the granites of this complex.

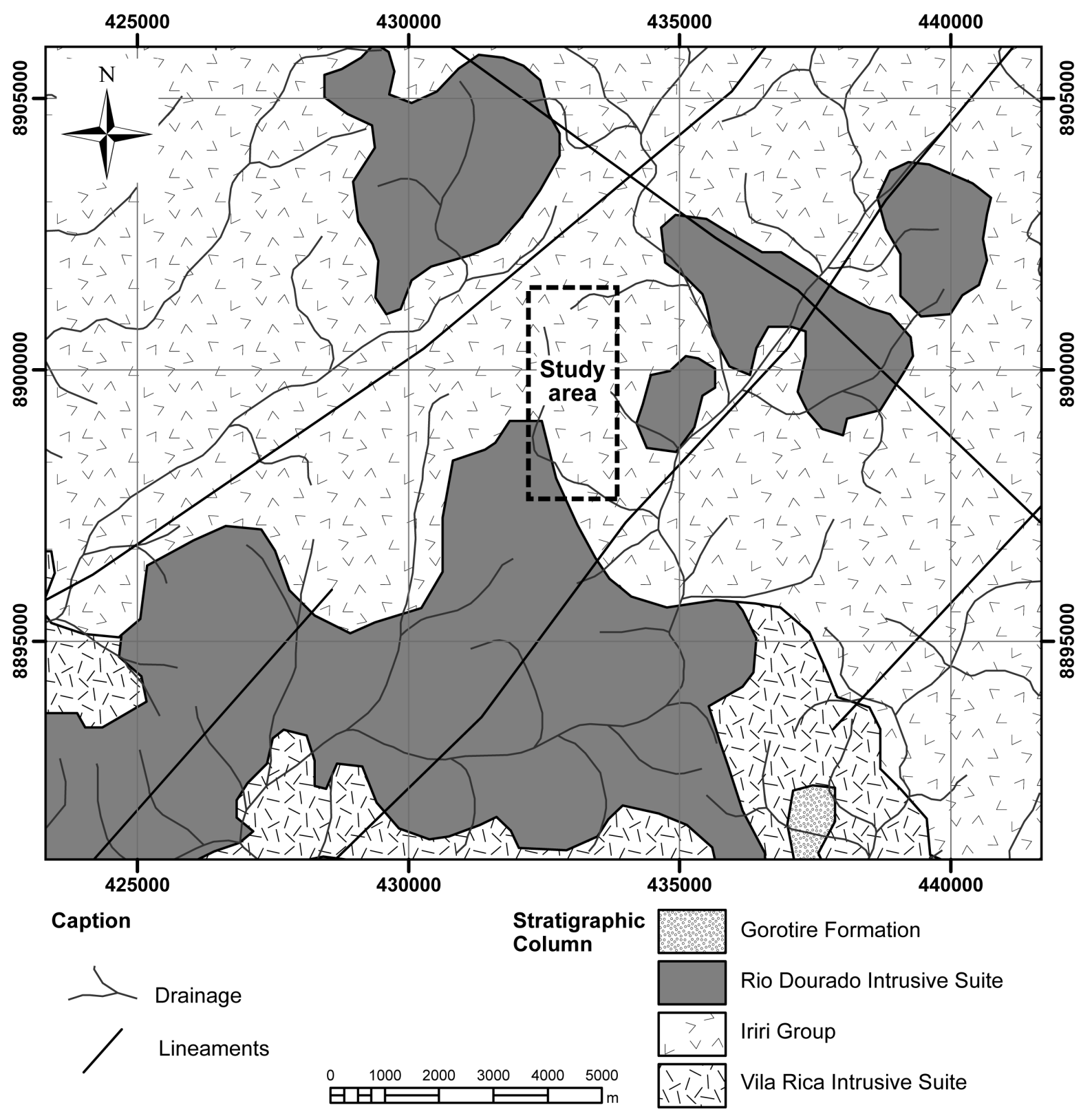

Figure 3 - Regional geological map of the study area (adapted from Alves et al. 2010). 
DOME GEOLOGY The Lava Dome of Sonho Meu Farm crops out as small hills of moderate height (Fig. 5A), geographically associated with the granites of Rio Dourado Intrusive Association. The dome is approximately $2000 \mathrm{~m}$ long and $250 \mathrm{~m}$ wide. Based on field data and petrographic studies, this unit was divided into four facies from
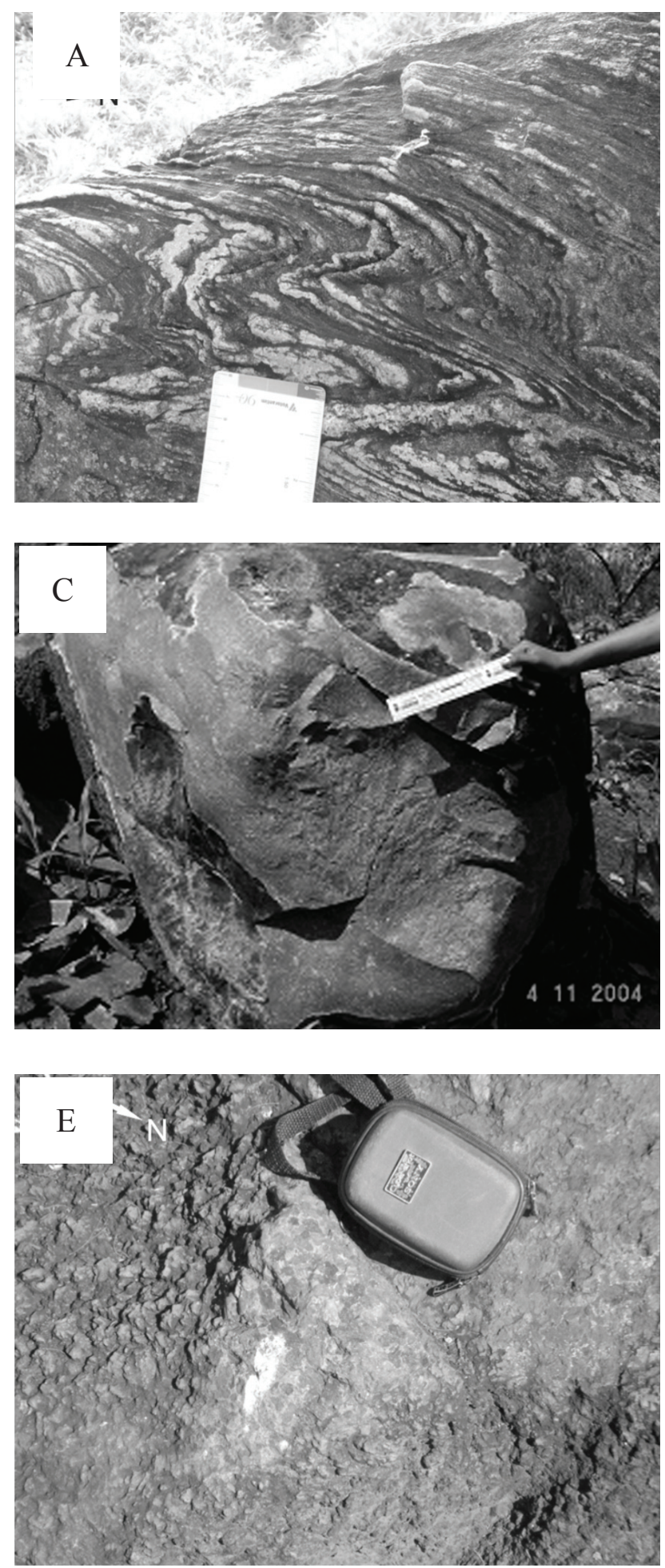

the dome core to the margin: coherent facies of the dome core (Fig. 5B); transitional autoclastic facies with tuff-like texture (Fig. 5C); facies of heterogeneous mixture of magmas (Fig 5D); and facies of the margin with well-marked magma flow structures (Figs. 5E, F). A schematic profile of the dome is shown in Fig. 6.
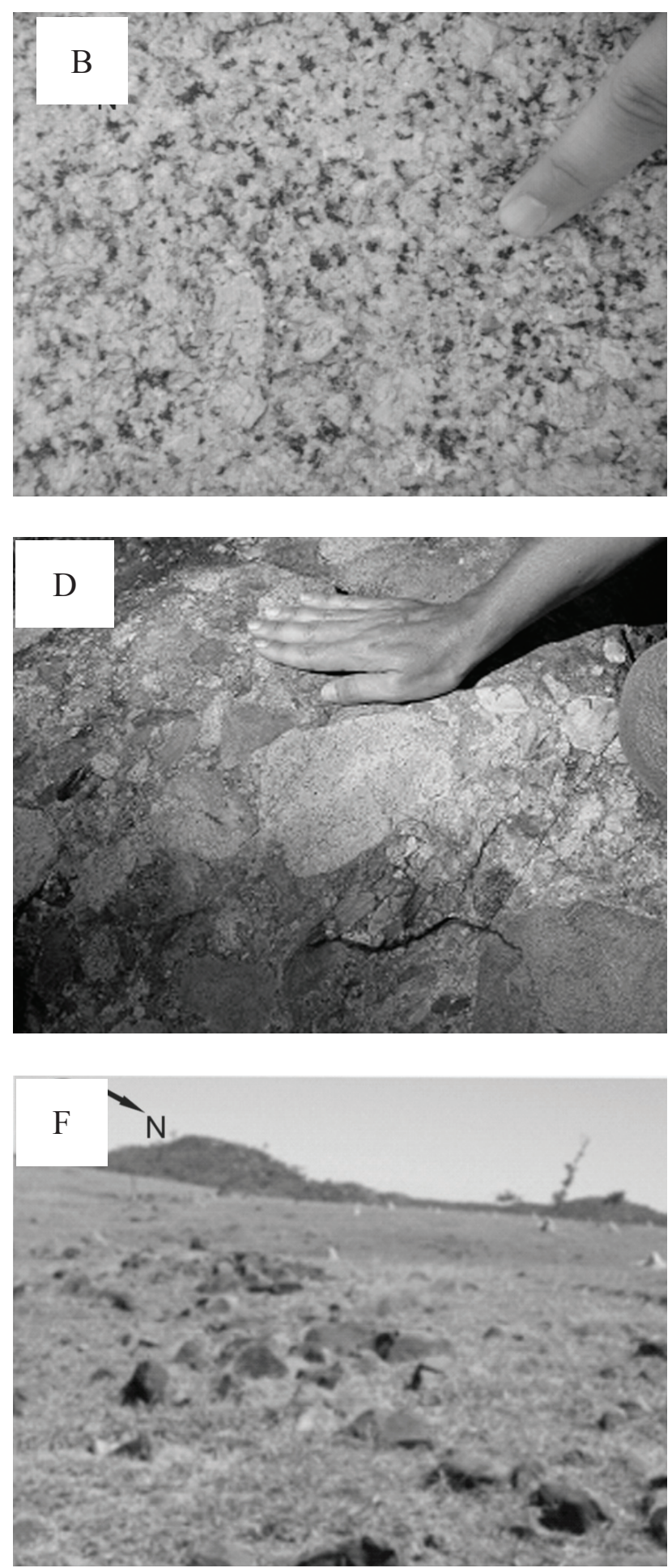

Figure 4 - (A) Highly deformed monzogranitic orthogneisses of the Vila Rica Intrusive Suite; (B) Syenogranites of the Rio Dourado Intrusive Suite; (C) Intermediate porphyritic volcanic rocks of the Iriri Group; (D) Pyroclastic breccias of the Iriri Group; (E) Olivine and hornblende gabbros of the Santa Inês Intrusive Suite; (F) Diabase dikes. 
The core facies displays coherent textures, which were formed by the cooling and solidification of the dome. Euhedral crystals and porphyritic texture are typical of this facies. The transitional facies is characterized by clear coehent (phenocrysts), autoclastic, and volcaniclastic textures (McPhie et al. 1993). The volcaniclastic texture is similar to that of ignimbrite or flow lithic breccias, and the texture pattern is tuff-like.
The facies of heterogeneous magmas mixture differs from that above mentioned due to its mingling texture, which indicates a partial and heterogeneous mixture between mafic and felsic magmas. The facies of the margin has a prominent magmatic flow structure, confirming that the magma was emplaced as a non particulate coherent system (dome), although the dome inner parts have tuff-like textures.
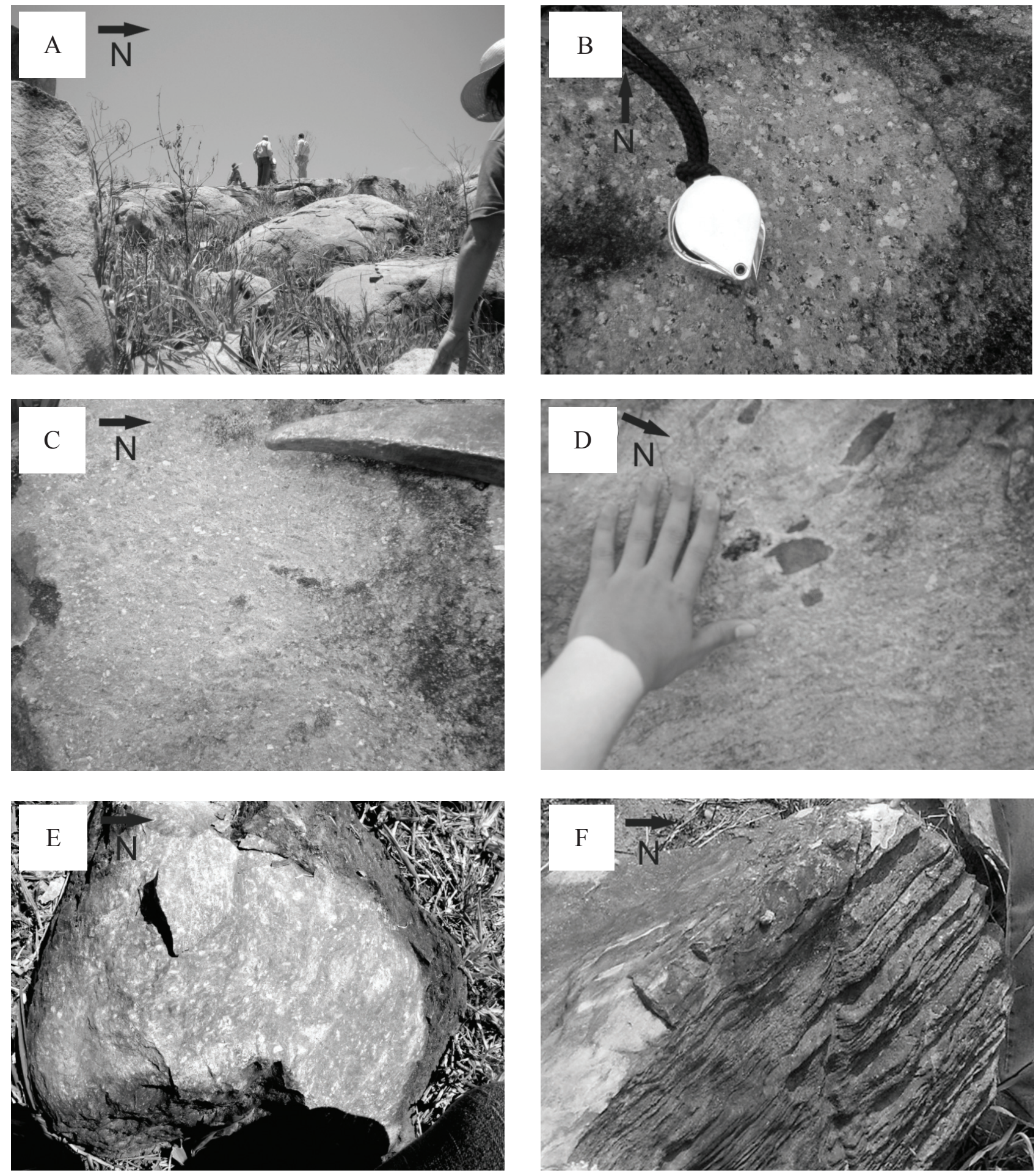

Figure 5-Field characteristics of the rocks of the dome body. (A) Mode of occurrence in the field. (B) Porphyritic texture of the core. (C) Tuff-like features similar to parataxitic textures. (D) Features of heterogeneous mixture of magmas (mingling). (E,F) Lavas with flow structures. 
Light grey lithotypes with porphyritic texture crop out in the transitional autoclastic facies with tuff-like textures. The fragmented textures are similar to those produced by flattening, such as the parataxitic and eutaxitic ones. Manley (1996) interprets tuff-like textures as being produced during the emplacement of felsic domes.

Mafic enclaves, characterized by high concentrations of amphibole that ranges from millimeters to centimeters $(5$ to $20 \mathrm{~cm}$ ) in size are surrounded by felsic material, developing facies with typical characteristics of a heterogeneous mixture of magmas.

\section{DOME PETROGRAPHY}

Coherent facies of the core The rock is holocrystalline with porphyritic texture and phenocrysts of alkali feldspar, plagioclase, and hornblende. The matrix is predominantly composed of quartz and alkali feldspar, and graphic intergrowth texture is common. The proportion of phenocrysts and matrix is 50 and $40 \%$, respectively.

Alkali feldspar phenocrysts occur as subhedral prisms up to $5 \mathrm{~mm}$ long, and most of them show an alteration similar to argilization, which pigments them to a reddish tonality under natural light. Plagioclase occurs as prismatic phenocrysts up to 4 $\mathrm{mm}$ long, which are often zoned, attached, and partially altered to white mica. Hornblende phenocrysts are dark green to yellowish green, up to $3 \mathrm{~mm}$ long, and sometimes they have a poikilitic texture. Biotite and chlorite are subproducts of mafic mineral alteration. Accessory minerals are: zircon, allanite, titanite, apatite, and opaque minerals (Fig. 7).

\section{Transitional autoclastic facies with tuff-like tex-} tures Pumice, shards, phenocrysts, crystal clasts, and lithoclasts were identified in this facies. They are usually found in pyroclastic deposits, although they are not necessarily exclusive of these deposits. According to Manley (1996), these fragmented textures characteristic of ignimbrites may be defined as tuff-like in lava domes and feeder dike systems. The decompression during the lava dome extrusion causes a quick increase in magma gases and consequent microvesiculation, which when stimulated by the flow may break the system, producing pumice, shards, massive glass fragments, and crystal clasts. The final result is a vitrophyre with autoclastic features and heterogeneous texture, whose flow foliations and components are similar to those of pyroclastic rocks with parataxitic and eutaxitic textures.

This facies is characterized by pumice, crystal clasts, cognate and accidental lithic fragments, and features of high-temperature compaction. Porphyritic and glomeroporphyritic texture, which are typical of lavas, also occur in this facies. The distinction between these two textures is made using the fragmented geometry of the minerals, especially the plagioclase and hornblende ones, which are sub-rounded to angular, and corrosion features in amphibole are also common.

Pumice is ellipsoidal and usually devitrified to a mosaic of alkali feldspar and quartz. Microdiorite

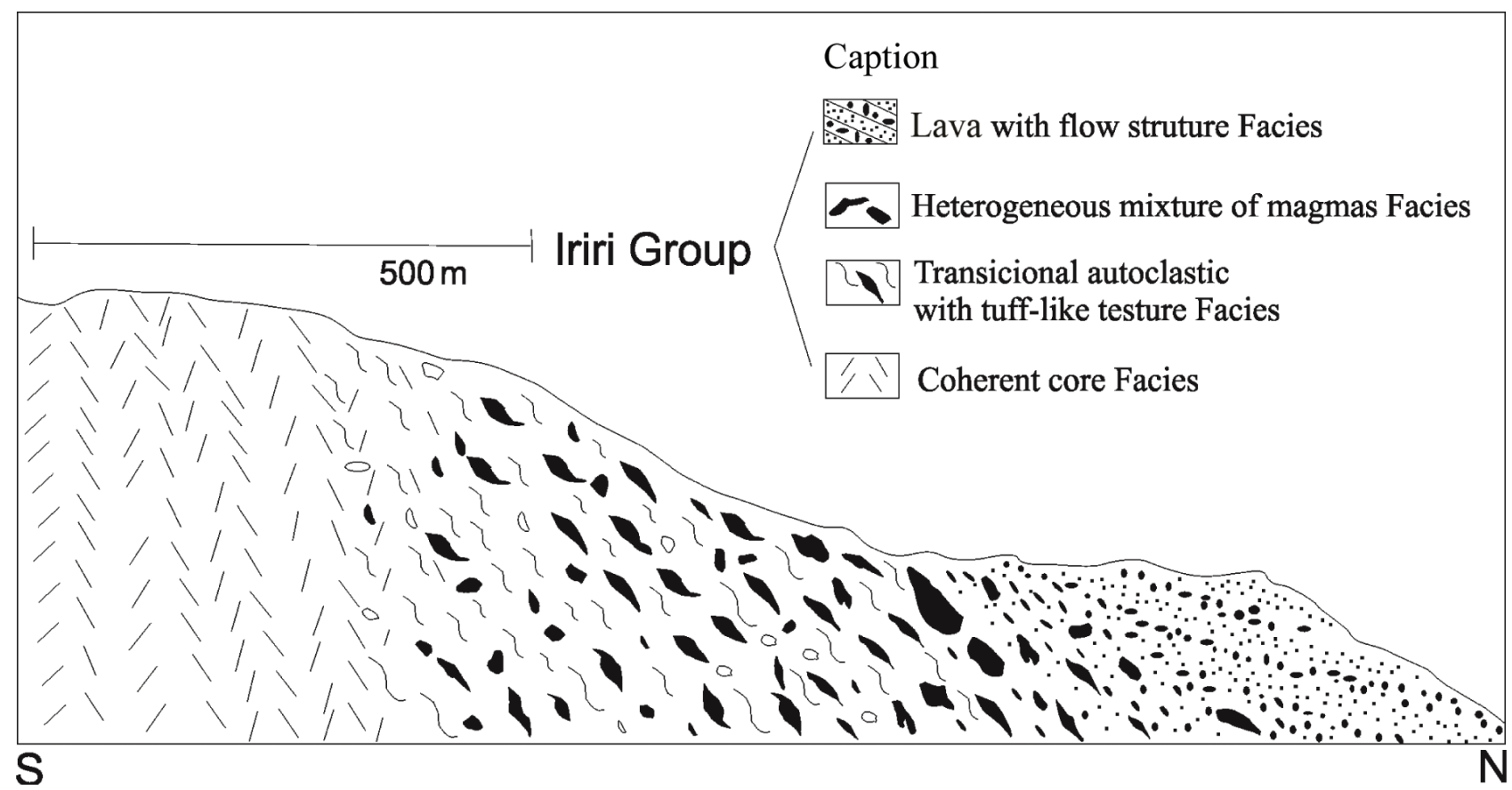

Figure 6-Schematic profile of the dome and its facies. 
enclaves and pyroxene segregations show several shapes, such as rounded (corrosion borders) and triangular (fragmented), ranging from 2 to $4 \mathrm{~mm}$. Rock fragments corroded by assimilation processes, all embedded in a very fine-grained felsitic matrix, are very common.

In the crystal clast-rich facies, the glomeroporphyritic texture is defined by clusters of mafic minerals, such as hornblende, biotite, and opaques. Compaction of pumice and vitroclasts produces a texture similar to the eutaxitic one, which is also characterized by the alignment of mafic minerals (mainly biotite) and pumice that surround the crystal clasts.

In the autoclastic facies, a magmatic foliation with folds along the rotated crystals, producing a texture similar to the parataxitic one, is observed. In this case, the vitroclasts are highly compacted. A laminar flow similar to that of lavas was macroscopically observed, and the spacing between the levels could reach a few millimeters. The rheomorphic features were produced by the behavior of a highly viscous flow, which broke and then the components were regrouped.

In thin sections, it may be mistaken for crystalrich ignimbrites, although mineral resorption (corrosion) and matrix crystallization are distinguishing features of this facies (Fig. 8).

Facies of heterogeneous mixture of magmas - mingling The lateral continuity of the facies is approximately $500 \mathrm{~m}$. This facies is characterized by a felsic rock with micro-porphyritic texture, in which alkali feldspar phenocrysts have features of solid-liquid imbalance. The felsic rocks host millimetric to centimetric, subrounded to angular (Fig. 9A) microdiorite enclaves (Fig. 5D), which are dispersed over a considerable distance $(300 \mathrm{~m})$. The enclaves have transitional contact with the host rock (Fig. 9B) and alkali feldspar xenocrysts with internal corrosion borders, suggesting heterogeneous mixture of magmas (mingling). Once
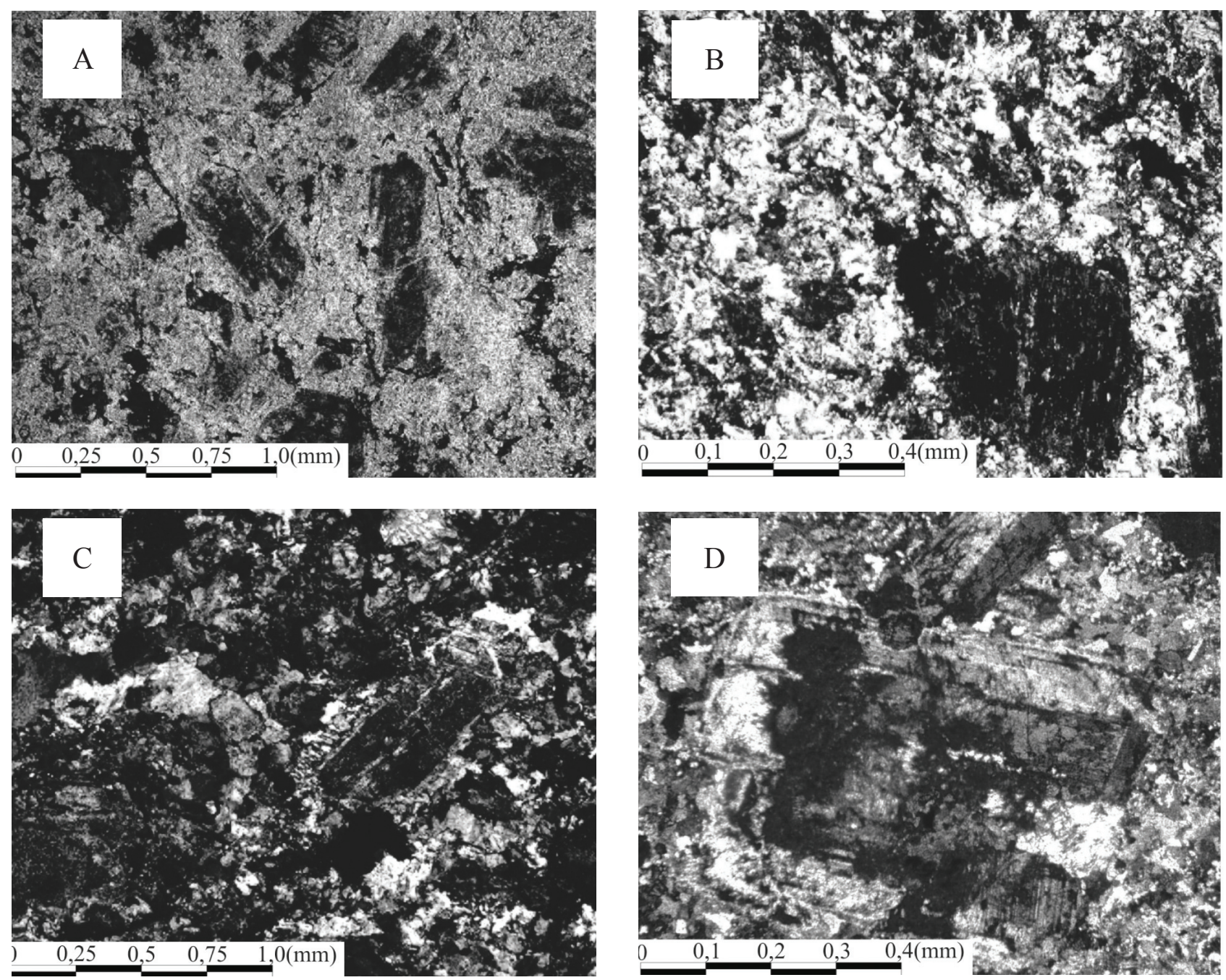

Figure 7 - Microscopic aspects of coherent facies (core). (A) Porphyritic rock with phenocrysts of argilized alkali feldspar, parallel nicols. (B) Details of hornblende phenocrysts in fine-grained matrix, crossed nicols. (C) Details of felsitic matrix with granophyric intergrowth, crossed nicols. (D) Phenocrysts of zoned and altered plagioclase, crossed nicols. 
the interaction between mafic and felsic magmas becomes greater, the enclave texture becomes microporphyritic with hornblende and biotite phenocrysts in a matrix with quartz and plagioclase. The imbalance conditions are evidenced by corrosion features and by the reabsorption of hornblende and biotite phenocrysts (Fig. 9C). The bigger enclaves have fine-grained inequigranular phaneritic texture, and they are composed predominantly of elongated prisms of hornblende (up to $3 \mathrm{~mm}$ ) and smaller plagioclase grains (up to $1 \mathrm{~mm}$ ), which are zoned and partially saussuritized (Fig. 9D). These characteristics, in addition to the lack of imbalance features, suggest a limited interaction between felsic and mafic magmas.

\section{Facies of lava with flow structures This facies} is characterized by preserving magmatic flow structures characterized by the alternation of layers with granulometric variations. The thinner layers are equigranular and composed of quartz, alkali feldspar, plagioclase, amphibole, biotite, and accessory minerals, they also have an average grain diameter of approximately $0.1 \mathrm{~mm}$.

The thicker layers are inequigranular and crystals have an average diameter of approximately $0.25 \mathrm{~mm}$. They have the same mineralogy of the thinner layers, and the alkali feldspar is dominant. Moderate mafic mineral (biotite) alignment and flattening were observed in both layers.

GEOCHEMISTRY Results of the chemical analyses of 14 samples from the dome of Sonho Meu Farm are presented in Tab. 1.

Samples in the TAS $\left(\mathrm{Na}_{2} \mathrm{O}+\mathrm{K}_{2} \mathrm{O}\right)$ versus $\mathrm{SiO}_{2}$ diagram (Le Maitre, 1989) plot in the trachyandesite, dacite, and trachyte fields (Fig. 10A) and in the limit zone between subalkaline and alkaline systems. In the R1-R2 diagram of De La Roche et al. (1980), as seen in Fig. 10B, samples are plotted in the latiandesite, dacite, rhyodacite, and rhyolite fields. In both diagrams, samples set a trend compatible with subalkaline magmas.
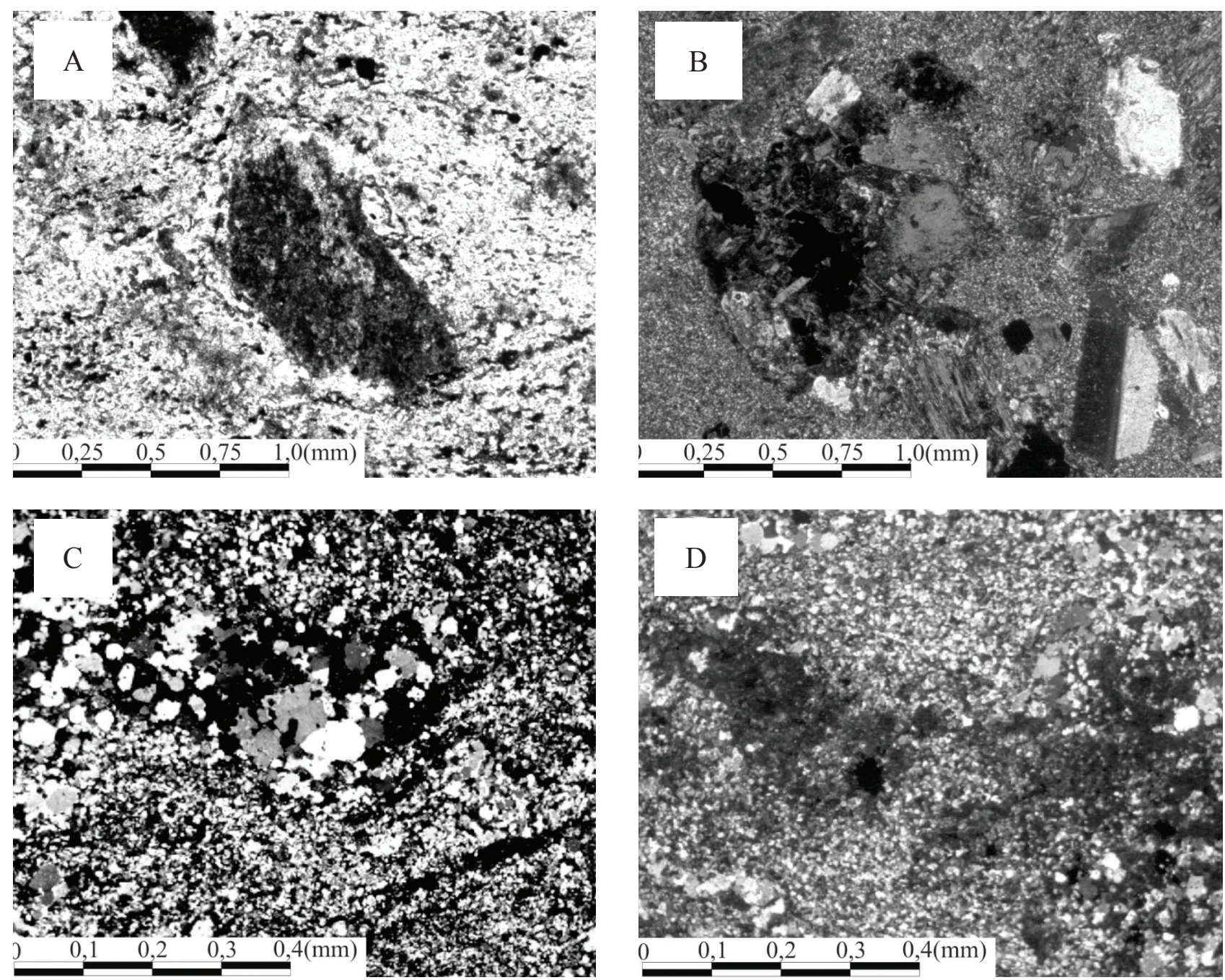

Figure 8 - (A) Tuff-like texture, preferential direction of the flow, parallel nicols. (B) Mafic mineral clusters, crossed nicols. (C) Devitrified pumice in felsitic matrix, crossed nicols. (D) Resorpted lithoclast, crossed nicols. 
In the $\mathrm{SiO}_{2}$ versus $\mathrm{K}_{2} \mathrm{O}$ diagram, which is used to classify the subalkaline rocks, samples plot mainly in the high-K calcalkaline field (Fig. 11A). The diagram made by Maniar \& Piccoli (1989) shows the metaluminous to peraluminous characters of the samples (Fig. 11B). $\mathrm{Rb}$ versus $\mathrm{Y}+\mathrm{Nb}$ contents plot in the diagram of Pearce et al. (1984) in the field of the post-collisional granites described by Pearce (1996) and show a trend towards the volcanic-arc granites field (Fig. 12).
The distribution pattern of major elements versus silica in the Harker-type binary diagrams (Fig. 13) indicates that $\mathrm{Al}_{2} \mathrm{O}_{3}, \mathrm{CaO}, \mathrm{MnO}, \mathrm{MgO}$, and $\mathrm{Fe}_{2} \mathrm{O}_{3}$ contents tend to decrease with differentiation, whereas $\mathrm{Na}_{2} \mathrm{O}$ content shows variations and $\mathrm{K}_{2} \mathrm{O}$ and $\mathrm{TiO}_{2}$ contents are higher with the increase in $\mathrm{SiO}_{2}$. These geochemical patterns suggest that, although there are suggestive features and magma mingling, plagioclase + hornblende fractionated crystallization was

Table 1 - Geochemical data from samples of the dome of Sonho Meu Farm

\begin{tabular}{|c|c|c|c|c|c|c|c|c|c|c|c|c|c|c|}
\hline Sample & MA04A & MA06 & MA07 & MA09 & MA14 & MA16 & FERA04 & FERA13 & FERA18 & FERA19 & FERA39 & MA20A & MA21 & MA24 \\
\hline $\mathrm{SiO}_{2}$ & 64.31 & 66.41 & 62.20 & 64.54 & 64.49 & 63.20 & 62.33 & 66.84 & 63.68 & 67.11 & 59.37 & 67.19 & 67.21 & 67.33 \\
\hline $\mathrm{Al}_{2} \mathrm{O}_{3}$ & 16.14 & 15.29 & 15.73 & 15.78 & 15.24 & 17.29 & 15.52 & 15.16 & 17.15 & 15.71 & 18.17 & 16.36 & 15.35 & 15.43 \\
\hline $\mathrm{Fe}_{2} \mathrm{O}_{3} \mathrm{t}$ & 4.47 & 4.45 & 5.90 & 4.90 & 5.38 & 4.69 & 5.46 & 4.23 & 4.27 & 3.41 & 6.40 & 3.18 & 3.60 & 3.62 \\
\hline $\mathrm{FeOt}$ & 4.02 & 4.00 & 5.31 & 4.41 & 4.84 & 4.22 & 4.91 & 3.81 & 3.84 & 3.07 & 5.76 & 2.86 & 3.24 & 3.26 \\
\hline $\mathrm{MnO}$ & 0.07 & 0.08 & 0.09 & 0.08 & 0.13 & 0.08 & 0.08 & 0.07 & 0.05 & 0.04 & 0.12 & 0.07 & 0.07 & 0.07 \\
\hline $\mathrm{MgO}$ & 1.20 & 1.17 & 2.84 & 1.30 & 1.19 & 2.18 & 2.94 & 1.59 & 1.97 & 0.81 & 1.86 & 0.57 & 0.71 & 0.63 \\
\hline $\mathrm{CaO}$ & 4.67 & 2.38 & 4.66 & 3.33 & 3.39 & 4.33 & 4.87 & 2.96 & 3.20 & 2.33 & 5.04 & 2.11 & 1.31 & 2.21 \\
\hline $\mathrm{Na}_{2} \mathrm{O}$ & 3.69 & 3.37 & 3.24 & 3.88 & 4.04 & 3.72 & 3.70 & 3.46 & 3.46 & 3.78 & 3.64 & 3.73 & 2.06 & 3.64 \\
\hline $\mathrm{K}_{2} \mathrm{O}$ & 3.52 & 4.67 & 3.49 & 4.02 & 3.81 & 2.84 & 2.56 & 4.21 & 4.63 & 5.30 & 3.35 & 5.32 & 7.61 & 5.47 \\
\hline $\mathrm{TiO}_{2}$ & 0.56 & 0.78 & 0.59 & 0.76 & 0.93 & 0.56 & 0.51 & 0.48 & 0.43 & 0.44 & 0.38 & 0.65 & 0.80 & 0.62 \\
\hline $\mathrm{P}_{2} \mathrm{O}_{5}$ & 0.19 & 0.23 & 0.21 & 0.29 & 0.30 & 0.19 & 0.20 & 0.13 & 0.17 & 0.13 & 0.28 & 0.17 & 0.15 & 0.18 \\
\hline P.F. & 1.00 & 0.70 & 0.80 & 0.90 & 0.80 & 0.70 & 1.50 & 0.60 & 0.70 & 0.70 & 1.00 & 0.50 & 0.90 & 0.60 \\
\hline Sum & 99.75 & 99.45 & 99.66 & 99.70 & 99.57 & 99.70 & 99.59 & 99.66 & 99.66 & 99.72 & 99.49 & 99.78 & 99.70 & 99.73 \\
\hline Mo & 0.50 & 0.80 & 1.60 & 1.20 & 1.00 & 0.30 & 0.40 & 1.20 & 0.10 & 0.60 & 0.40 & 1.70 & 0.70 & 1.40 \\
\hline $\mathrm{Cu}$ & 5.80 & 7.30 & 28.20 & 4.30 & 15.70 & 4.70 & 48.60 & 15.40 & 1.70 & 7.80 & 16.20 & 3.20 & 39.50 & 4.00 \\
\hline $\mathrm{Pb}$ & 3.30 & 8.90 & 7.20 & 7.80 & 9.90 & 4.00 & 3.20 & 9.30 & 5.00 & 7.70 & 5.60 & 11.90 & 9.90 & 11.50 \\
\hline $\mathrm{Zn}$ & 13.00 & 48.00 & 40.00 & 63.00 & 64.00 & 40.00 & 51.00 & 43.00 & 29.00 & 29.00 & 60.00 & 40.00 & 60.00 & 49.00 \\
\hline $\mathrm{Ni}$ & 0.10 & 2.00 & 15.50 & 2.60 & 2.80 & 10.60 & 25.10 & 9.60 & 12.60 & 3.90 & 1.60 & 1.10 & 1.10 & 2.30 \\
\hline $\mathrm{Sc}$ & 10.00 & 10.00 & 14.00 & 10.00 & 14.00 & 10.00 & 13.00 & 10.00 & 11.00 & 6.00 & 8.00 & 7.00 & 9.00 & 7.00 \\
\hline Co & 10.20 & 5.60 & 15.70 & 7.50 & 6.50 & 11.60 & 16.10 & 2.00 & 10.30 & 5.60 & 11.50 & 4.20 & 3.60 & 3.90 \\
\hline Cs & 4.10 & 3.90 & 5.40 & 4.40 & 3.90 & 8.20 & 0.80 & 2.80 & 8.60 & 6.00 & 1.60 & 7.10 & 7.70 & 3.80 \\
\hline $\mathrm{Ga}$ & 17.60 & 18.00 & 18.60 & 18.50 & 18.50 & 17.70 & 17.80 & 16.30 & 19.00 & 17.50 & 17.70 & 17.20 & 17.20 & 17.80 \\
\hline Hf & 4.60 & 6.00 & 4.60 & 6.00 & 7.20 & 5.30 & 3.70 & 4.90 & 6.10 & 5.40 & 3.80 & 6.60 & 7.10 & 6.30 \\
\hline $\mathrm{Nb}$ & 8.50 & 12.50 & 7.70 & 11.60 & 12.60 & 8.60 & 5.40 & 9.20 & 9.10 & 11.40 & 6.10 & 13.30 & 15.50 & 12.00 \\
\hline $\mathrm{Rb}$ & 118.8 & 159.0 & 127.1 & 147.0 & 127.5 & 176.1 & 59.1 & 129.3 & 186.1 & 189.4 & 79.5 & 189.4 & 251.9 & 172.1 \\
\hline $\mathrm{Sr}$ & 436.8 & 416.3 & 483.0 & 473.0 & 435.8 & 507.9 & 750.3 & 403.6 & 560.3 & 420.7 & 937.9 & 324.2 & 198.4 & 324.4 \\
\hline $\mathrm{Ta}$ & 0.50 & 0.80 & 0.70 & 0.90 & 0.90 & 0.60 & 0.40 & 0.70 & 0.70 & 0.90 & 0.30 & 1.20 & 1.10 & 1.00 \\
\hline Th & 12.40 & 18.40 & 12.30 & 16.10 & 13.70 & 14.20 & 6.00 & 14.20 & 14.60 & 17.50 & 5.70 & 19.90 & 18.70 & 17.60 \\
\hline $\mathrm{U}$ & 3.00 & 4.90 & 3.00 & 4.50 & 3.40 & 2.90 & 1.40 & 3.50 & 3.30 & 4.80 & 1.40 & 5.00 & 4.90 & 5.00 \\
\hline V & 69.00 & 56.00 & 102.00 & 63.00 & 38.00 & 70.00 & 92.00 & 56.00 & 61.00 & 38.00 & 89.00 & 35.00 & 40.00 & 36.00 \\
\hline $\mathrm{W}$ & 0.80 & 1.80 & 1.20 & 2.20 & 2.10 & 0.60 & 0.90 & 1.40 & 0.80 & 1.60 & & 2.40 & 1.70 & 1.80 \\
\hline $\mathrm{Zr}$ & 182.8 & 231.1 & 169.2 & 220.9 & 295.0 & 190.0 & 137.1 & 186.8 & 215.1 & 196.9 & 134.4 & 232.9 & 264.3 & 238.7 \\
\hline $\mathrm{Y}$ & 16.70 & 22.50 & 16.60 & 21.90 & 31.60 & 16.90 & 11.40 & 16.40 & 23.70 & 14.70 & 12.80 & 21.10 & 23.90 & 21.60 \\
\hline $\mathrm{Ba}$ & 1,090 & 1,404 & 1,012 & 1,182 & 1,430 & 1,076 & 1,112 & 1,287 & 1,210 & 1,155 & 1,455 & 1,020 & 1,282 & 1,267 \\
\hline $\mathrm{La}$ & 32.80 & 51.80 & 39.50 & 46.70 & 52.60 & 36.40 & 30.70 & 35.70 & 41.40 & 41.20 & 28.70 & 47.60 & 52.10 & 45.60 \\
\hline $\mathrm{Ce}$ & 67.40 & 99.70 & 74.00 & 94.90 & 102.20 & 72.70 & 61.00 & 69.60 & 77.40 & 78.60 & 55.20 & 95.60 & 108.30 & 90.90 \\
\hline $\operatorname{Pr}$ & 7.04 & 10.91 & 7.95 & 10.20 & 11.65 & 7.74 & 7.06 & 7.83 & 9.36 & 8.81 & 5.92 & 10.32 & 11.47 & 9.91 \\
\hline $\mathrm{Nd}$ & 26.10 & 39.50 & 28.60 & 36.30 & 42.30 & 27.00 & 27.60 & 28.80 & 33.70 & 30.40 & 22.00 & 38.20 & 41.60 & 36.10 \\
\hline $\mathrm{Sm}$ & 4.31 & 6.20 & 4.65 & 6.17 & 7.59 & 4.64 & 4.22 & 4.60 & 5.47 & 4.62 & 3.39 & 5.65 & 6.34 & 5.58 \\
\hline $\mathrm{Eu}$ & 0.97 & 1.39 & 1.10 & 1.38 & 2.19 & 1.07 & 1.17 & 1.00 & 1.12 & 0.92 & 0.98 & 1.16 & 1.34 & 1.08 \\
\hline $\mathrm{Gd}$ & 3.25 & 4.57 & 3.50 & 4.57 & 6.61 & 3.53 & 2.97 & 3.48 & 4.40 & 3.24 & 2.56 & 4.31 & 4.73 & 4.33 \\
\hline $\mathrm{Tb}$ & 0.53 & 0.70 & 0.54 & 0.69 & 1.01 & 0.56 & 0.42 & 0.52 & 0.71 & 0.49 & 0.41 & 0.68 & 0.72 & 0.68 \\
\hline Dy & 2.92 & 3.81 & 2.83 & 3.74 & 5.39 & 3.06 & 1.99 & 2.77 & 3.79 & 2.62 & 2.23 & 3.43 & 3.85 & 3.56 \\
\hline Ho & 0.56 & 0.75 & 0.53 & 0.72 & 1.06 & 0.61 & 0.37 & 0.52 & 0.75 & 0.49 & 0.42 & 0.70 & 0.76 & 0.70 \\
\hline Er & 1.68 & 2.21 & 1.49 & 2.22 & 3.13 & 1.72 & 0.99 & 1.53 & 2.25 & 1.42 & 1.29 & 2.02 & 2.28 & 2.04 \\
\hline $\mathrm{Tm}$ & 0.25 & 0.33 & 0.22 & 0.33 & 0.46 & 0.27 & 0.16 & 0.25 & 0.36 & 0.23 & 0.21 & 0.32 & 0.35 & 0.33 \\
\hline $\mathrm{Yb}$ & 1.64 & 2.14 & 1.43 & 2.22 & 2.97 & 1.83 & 0.99 & 1.48 & 2.24 & 1.46 & 1.36 & 2.02 & 2.29 & 2.03 \\
\hline $\mathrm{Lu}$ & 0.26 & 0.32 & 0.22 & 0.32 & 0.44 & 0.26 & 0.15 & 0.24 & 0.35 & 0.22 & 0.21 & 0.32 & 0.36 & 0.30 \\
\hline
\end{tabular}



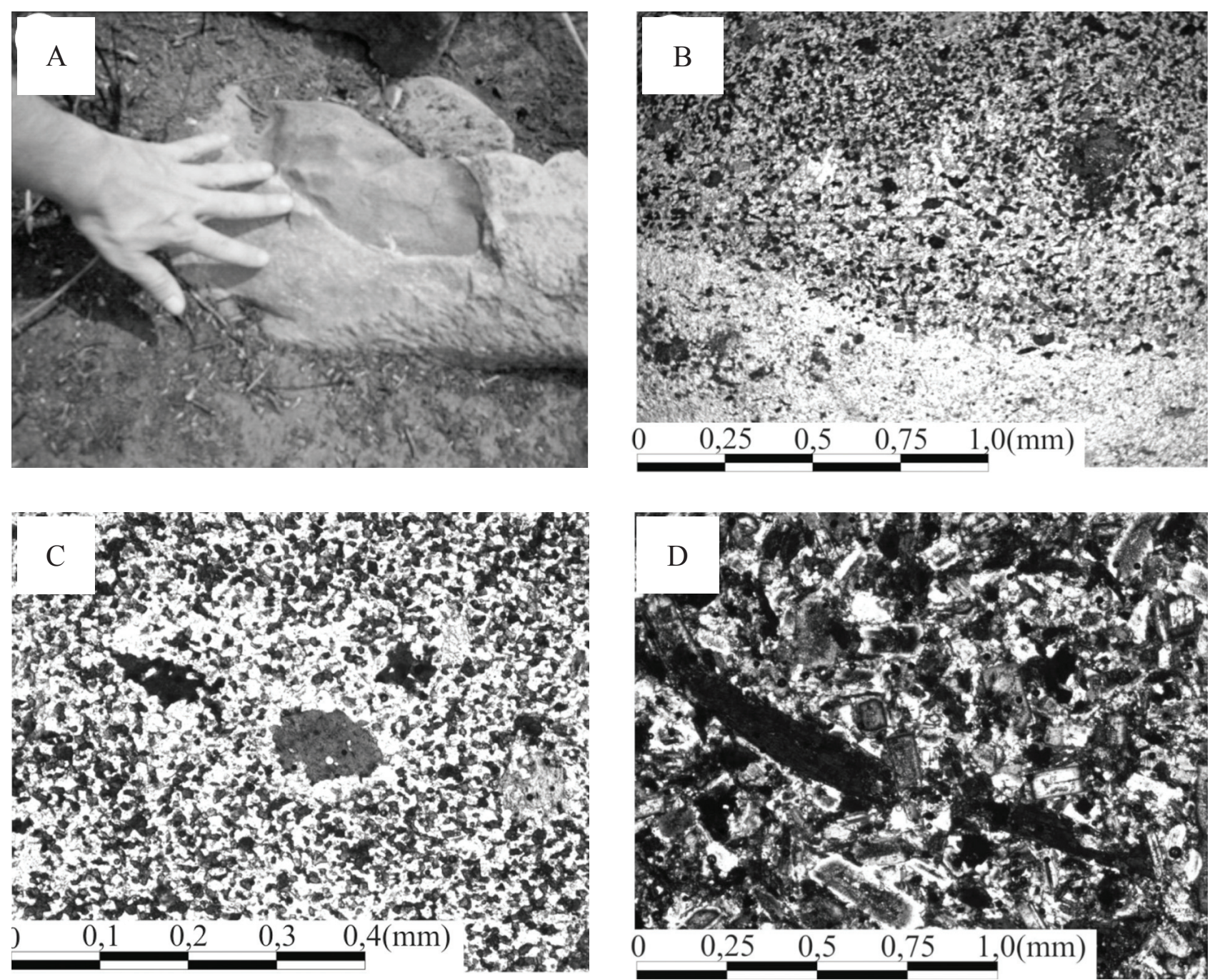

Figure 9 - (A) Subangular enclave with approximately $20 \mathrm{~cm}$. (B) Transitional contact zone between the microdioritic enclave and the felsic host rock, parallel nicols. (C) Corroded hornblende phenocrysts with inclusions, parallel nicols. (D) Inequigranular phaneritic texture with hornblende and zoned plagioclase crystals.
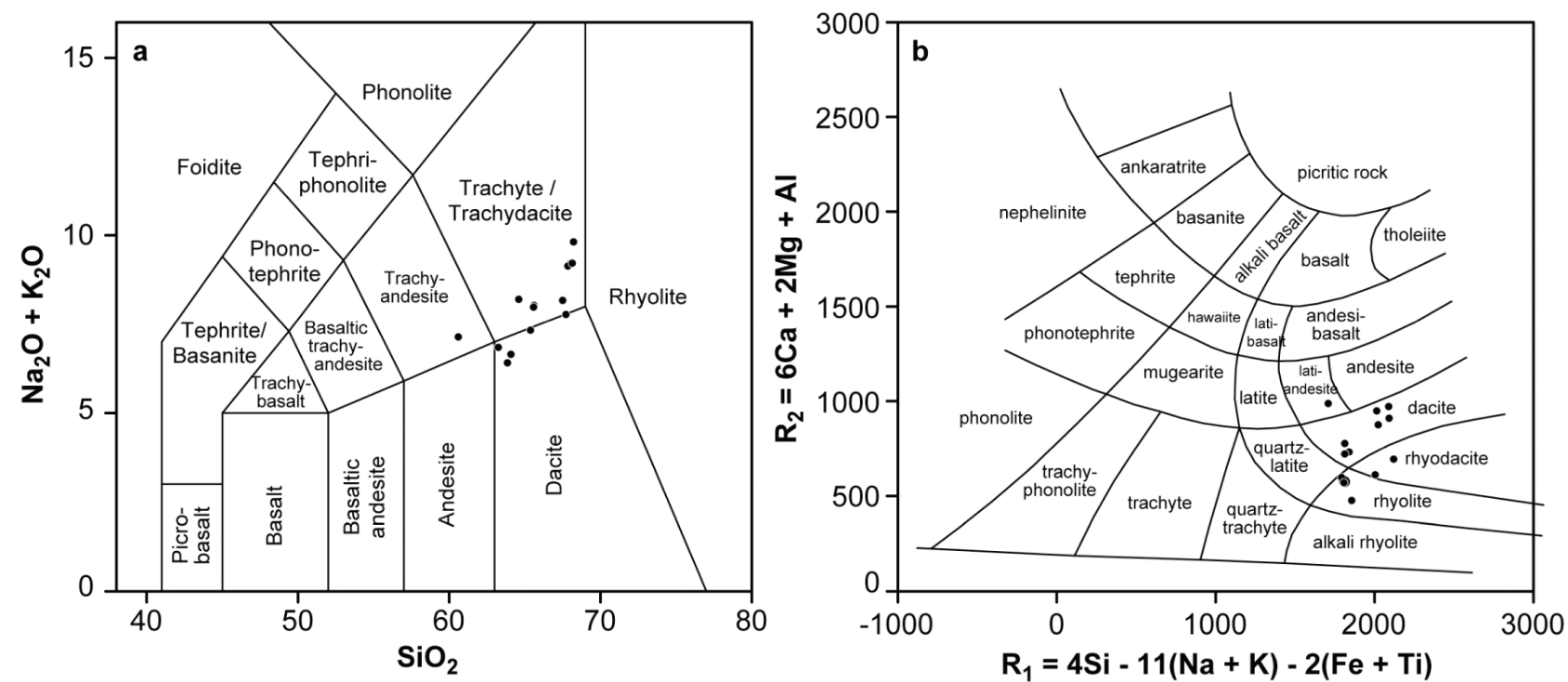

Figure 10 - Chemical classification of lava dome samples. (A) TAS diagram of Le Bas et al. (1986). (B) R1-R2 diagram of De La Roche et al. (1980). 

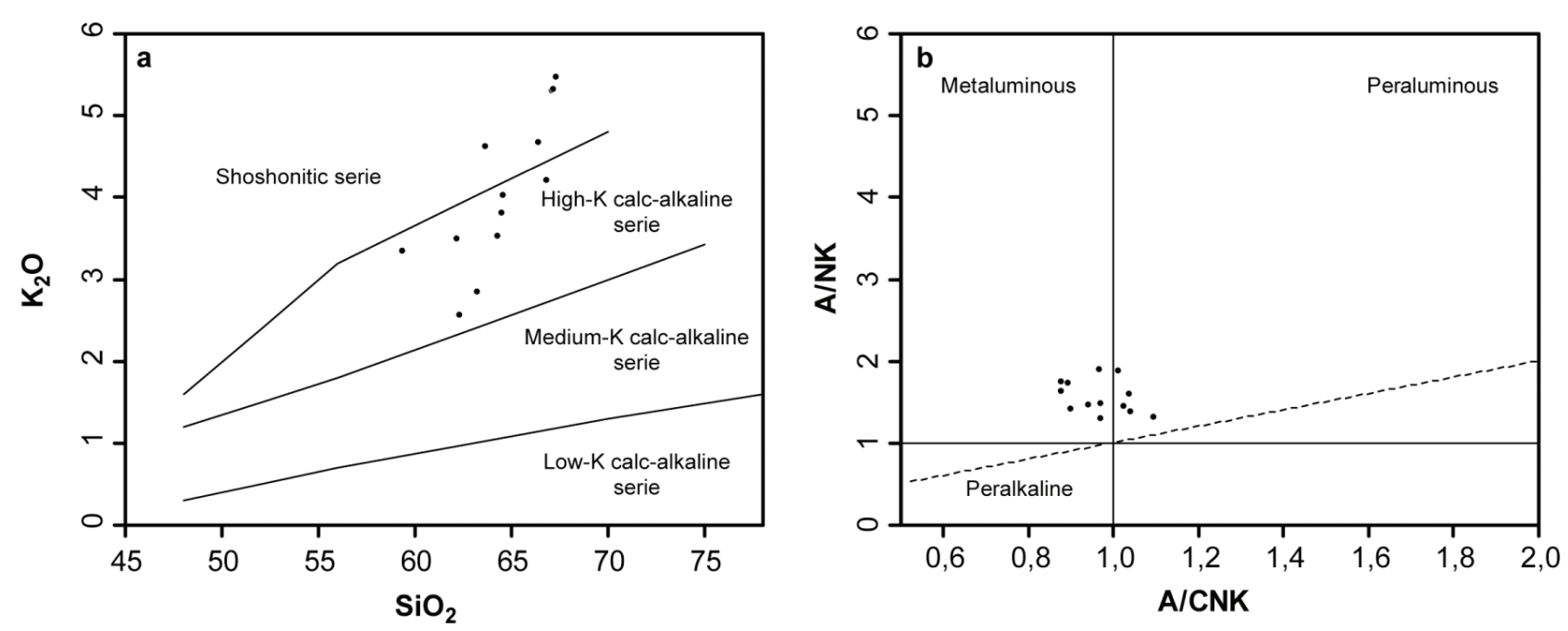

Figure 11 - (A) $\mathrm{SiO}_{2}$ versus $\mathrm{K}_{2} \mathrm{O}$ diagram of Peccerillo \& Taylor (1976). (B) ANK versus ACNK diagram of Maniar \& Piccoli (1989).

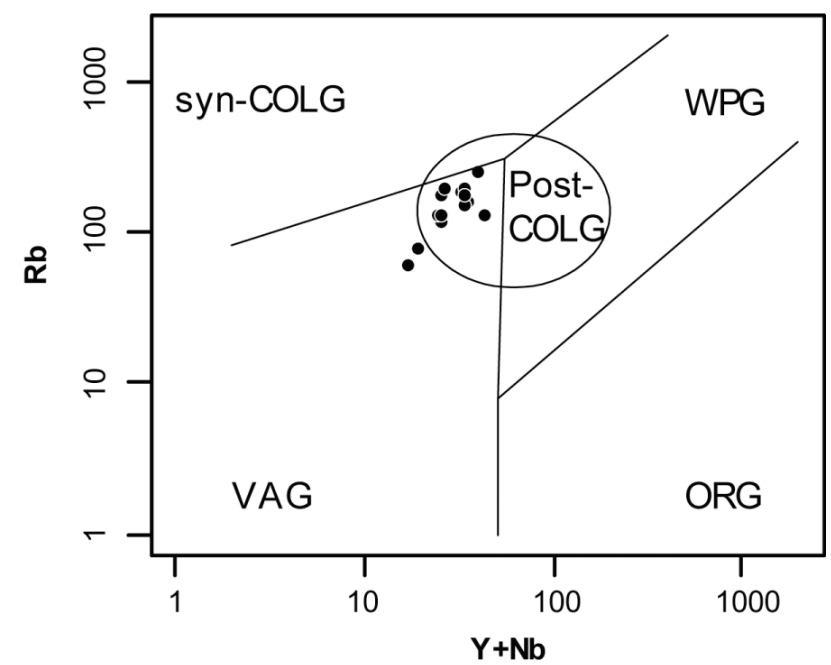

syn-COLG: syn-collisional granites; WPG: within plate granites; VAG: volcanic-arc granite; ORG: ocean-ridge granites; PostCOLG: post-collisional granite.

Figure 12 - Tectonic environment discrimination diagrams of Pearce et al. (1984) and Pearce (1996).

the main process in the magmatic evolution of the studied lithotypes. This hypothesis is coherent with the geochemical patterns of trace elements versus $\mathrm{Zr}$. The decrease in $\mathrm{Sr}, \mathrm{Ni}, \mathrm{Co}$ and $\mathrm{Cu}$ contents with the increase in $\mathrm{Zr}$ one shows the compatibility of these elements during the differentiation, whereas the increase in $\mathrm{Rb}, \mathrm{Pb}, \mathrm{Nb}$, Th, Hf, Y, La and Lu contents shows the incompatibility of these elements with the extracted phases (Fig. 14).

Rare-earth elements (REE), patterns of these rocks, normalized to $\mathrm{C} 1$ chondrite of Sun \& McDonough (1989), show a slight light rare earth elements (LREE ) enrichment over the heavy rare elements (HREE) (Fig. 15a). An increase in the total REE content is observed with differentiation. Weak or no Eu negative anomalies may be explained by the effect of the mafic phase (amphibole and/or pyroxene) extraction with no accumulation of $\mathrm{Eu}$, which would offset the content decrease with the fractionation of plagioclase. Therefore, this hypothesis includes mafic phase fractionation, during the evolution of the studied lithotypes.

In the multielement diagram, which was normalized to ocean-ridge granite of Pearce et al. (1984), as seen in Fig. 15B, the samples are characterized by an enrichment in large ion lithophile element - LILE ( $\mathrm{Ba}, \mathrm{Rb}, \mathrm{K}_{2} \mathrm{O}$, and high contents of $\mathrm{Sr}$ ) and high-field strength element (HFSE) negative anomaly ( $\mathrm{Ta}, \mathrm{Nb}$, $\mathrm{Hf}, \mathrm{Zr}$, and $\mathrm{Y}$ ). This geochemical pattern is common in shoshonitic and high-K calcalkaline associations related to lithospheric mantle sources, which were previously modified by subduction.

\section{ISOTOPIC GEOLOGY}

Results of $\mathbf{U} / \mathbf{P b}$ zircon dating Thirteen zircons ranging from 60 to $120 \mu \mathrm{m}$ were analyzed by LA-ICPMS. They occurred as light brown, anhedral to subhedral grains. Some crystals were elongated and others, rounded. In general, they were fractured and rarely preserved the prismatic features. Some crystals were slightly zoned and showed metamictized borders. Curvilinear contours resembled features produced by magmatic corrosion processes. Fig. 16 shows the analyzed crystals, as well as the laser beam positions.

Analytical data are presented in Tab. 2. U-Pb isotope analyses of 13 zircon crystals yielded an age of $1,878 \pm 12 \mathrm{Ma}$, which is shown in the concordia diagram in Fig. 17. 
${ }^{143} \mathrm{Nd} /{ }^{144} \mathrm{Nd}$ isotopic data $\mathrm{Nd}$ isotope data for two samples of volcanic rocks collected in the dome vicinity, considering $1.88 \mathrm{Ga}$ as the crystallization age, showed crustal residence values (TDM) ranging from

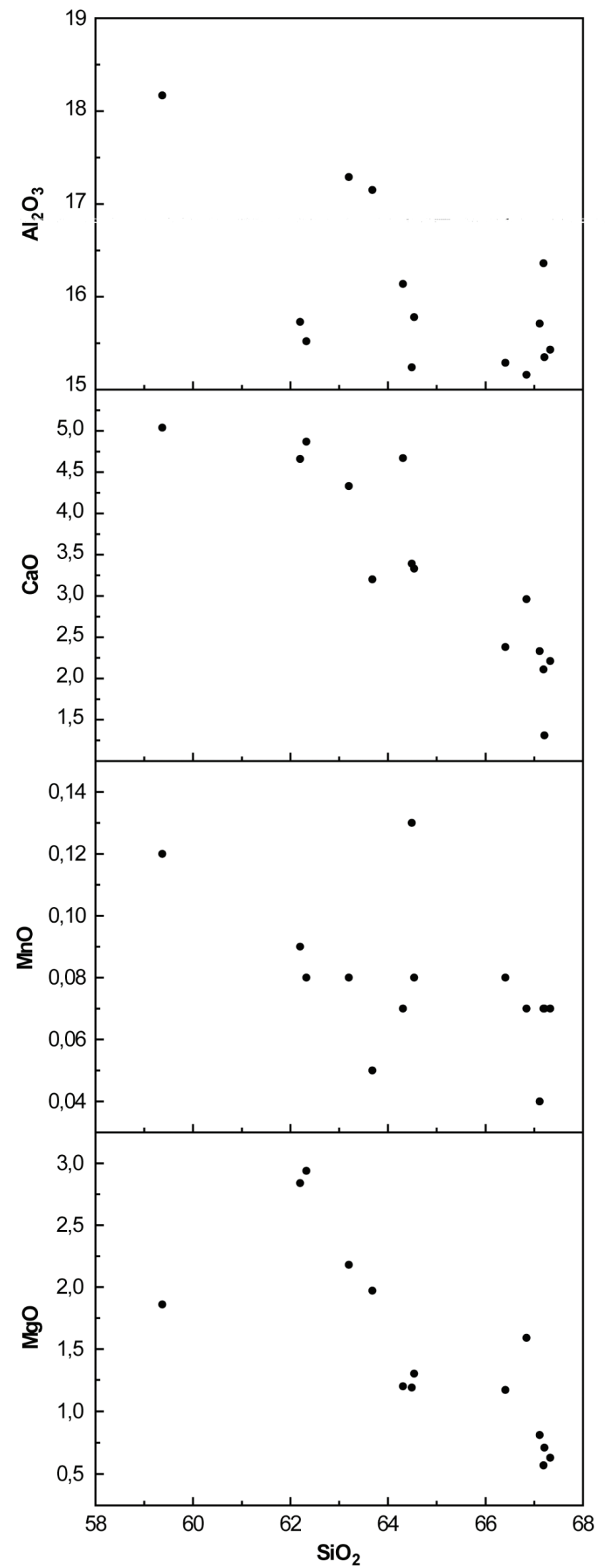

2.46 to 2.59 . $€ \mathrm{Nd}$ negative values ranging from -3.66 to -6.89 suggest that the crustal source was involved in the formation and/or evolution of the volcanic rocks of the Iriri Group in the studied area (Tab. 3).

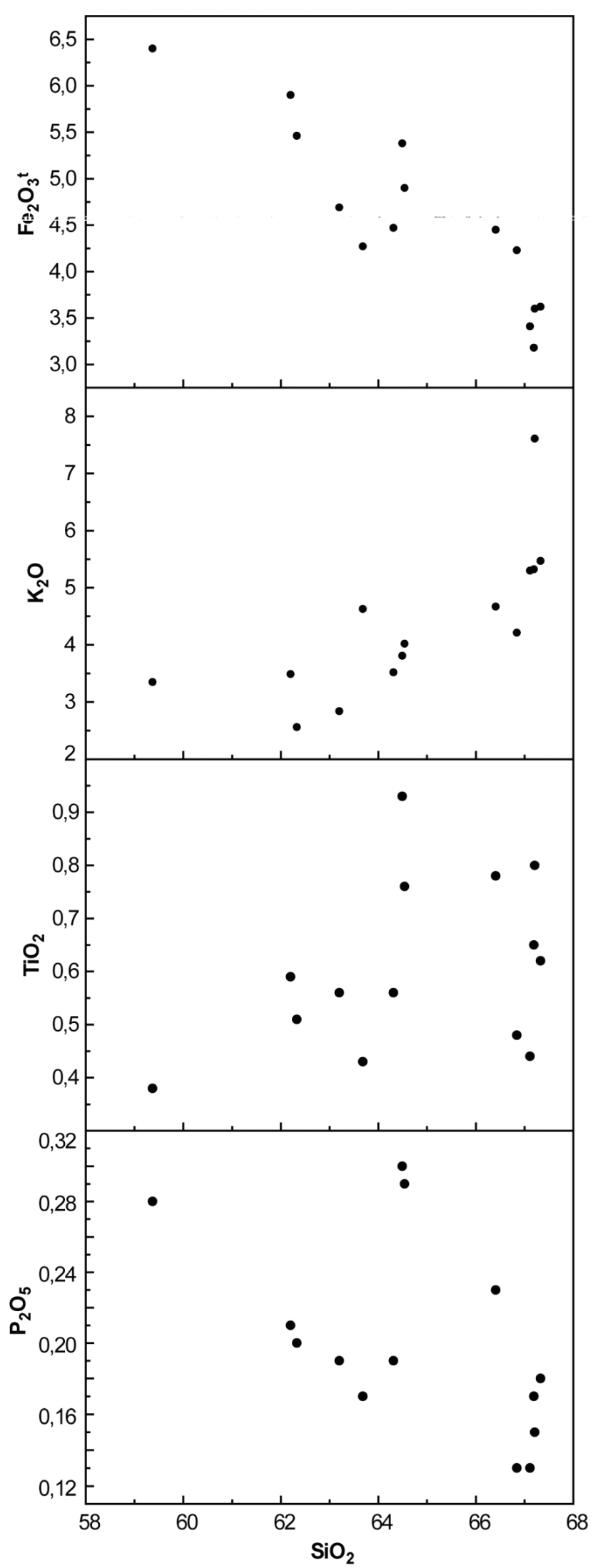

Figure 13 - Binary diagrams of the lava dome samples, using silica as a differentiation index. 

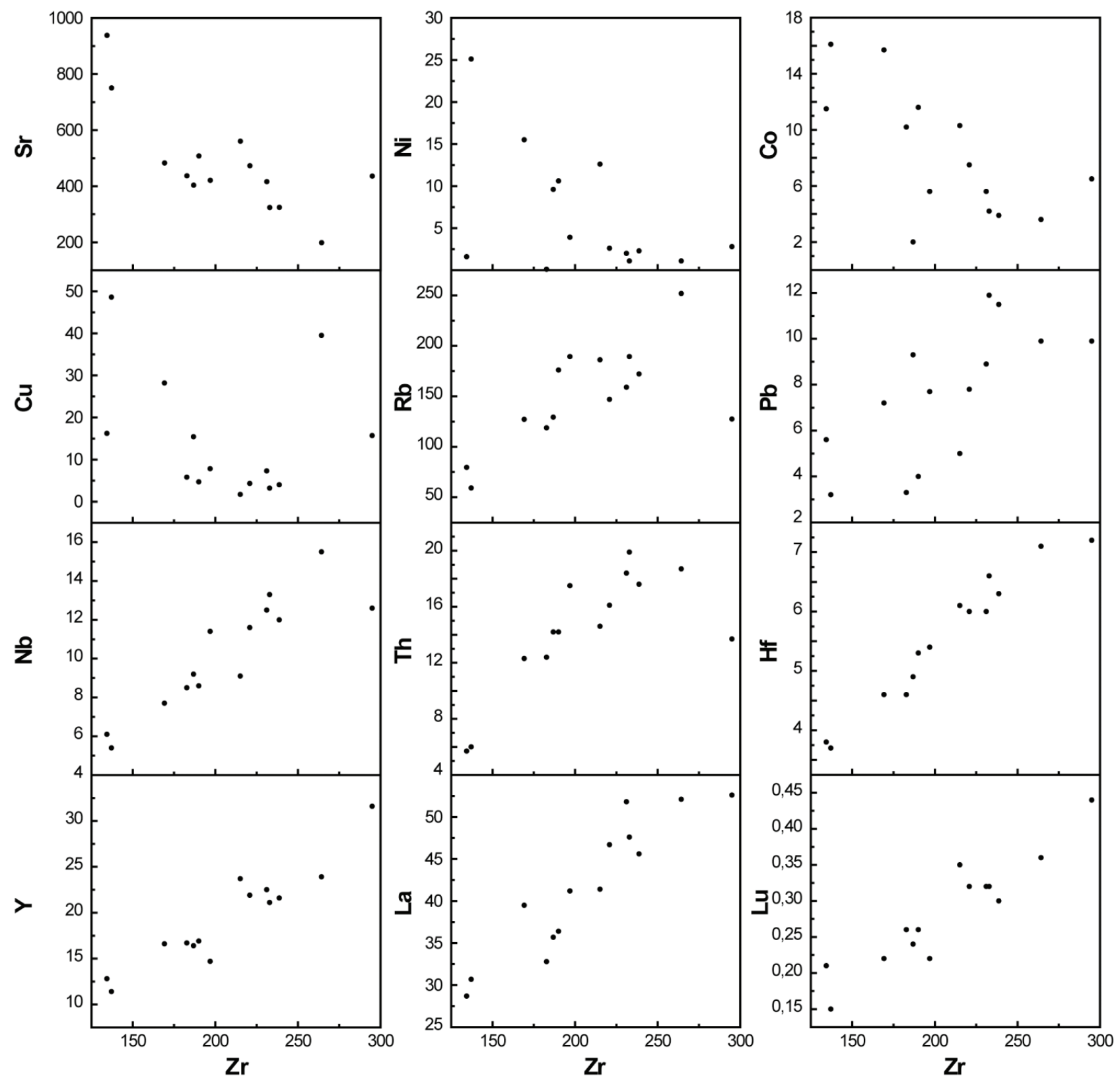

Figure 14 - Binary diagrams of the lava dome samples, using zirconium as a differentiation index.
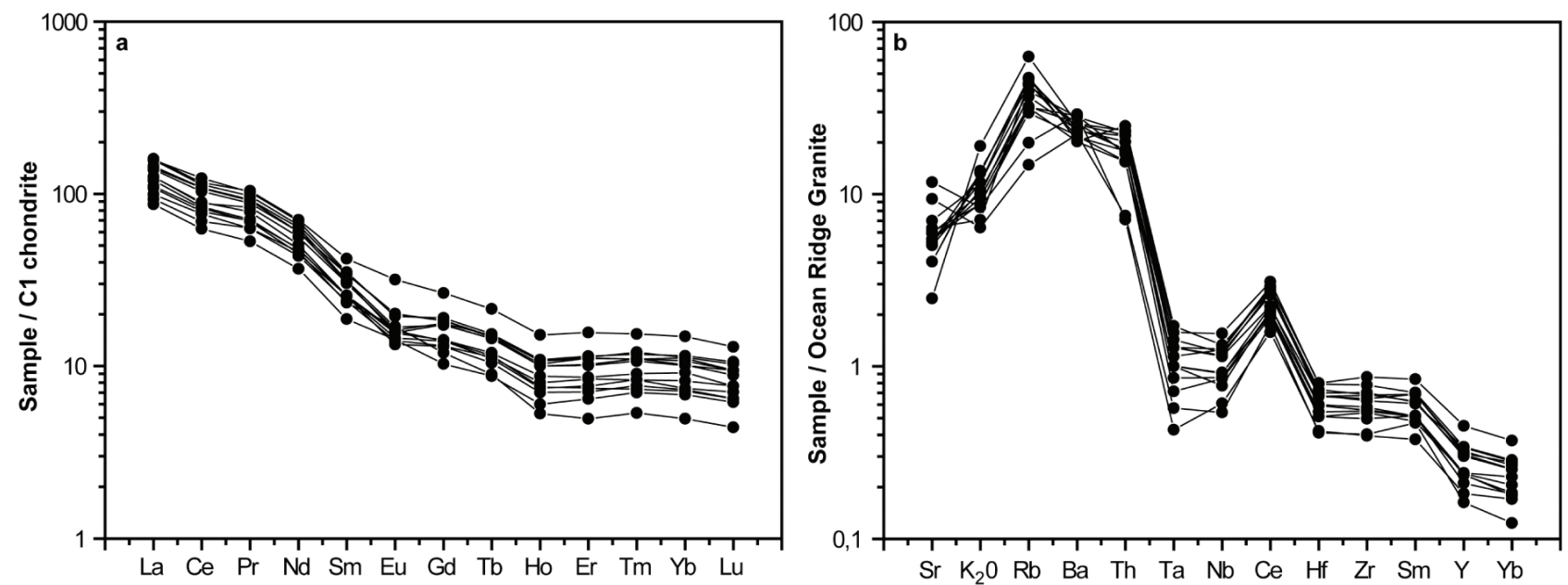

Figure 15 - Multielement diagrams for the lava dome samples normalized to chondritic values of: (A) Sun \& McDonough (1989) and (B) to ocean-ridge granite of Pearce et al. (1984). 
DISCUSSION AND CONCLUSIONS The Lava Dome of Sonho Meu Farm ranges from intermediate to acid in composition and cuts granitic rocks of the Rio Dourado Intrusive Suite. Four facies were identified in the Dome: coherent core; autoclastic with tuff-like texture; facies of heterogeneous mixture of magmas; and of lavas with magma flow structures. In the autoclastic facies and in the facies with magma flow structures, pumice, vitroclasts, massive glass fragments and crystal clasts, which are similar to fiamme and shards produced by deformation of welded ignimbrite, were observed. Decompression during extrusion and emplacement of the lava dome of Sonho Meu Farm caused intense microvesiculation and posterior flow comminution, producing pumice, shards, massive glass fragments, and crystal clasts. The facies with magma flow structures had textures similar to those of the rheomorphic ignimbrites. The texture patterns of the autoclastic facies and the facies with magma flow structures are similar to those observed in high-temperature pyroclastic flow deposits, in which parataxitic and eutaxitic textures are common. However, the facies arrangement of the Lava Dome of Sonho Meu Farm indicates that there was no explosive volcanic event during its formation. In this case, the fragmented textures identified in the dome were defined in this paper as tuff-like, as suggested by Manley (1996).

Geochemical studies indicate high-K calcalkaline affinity. The behavior of major and trace elements shown in binary diagrams indicates that the plagioclase and mafic phase fractionation was the dominant process in the petrogenetic evolution of the magma from which the studied rocks formed. Negative $€ \mathrm{Nd}$
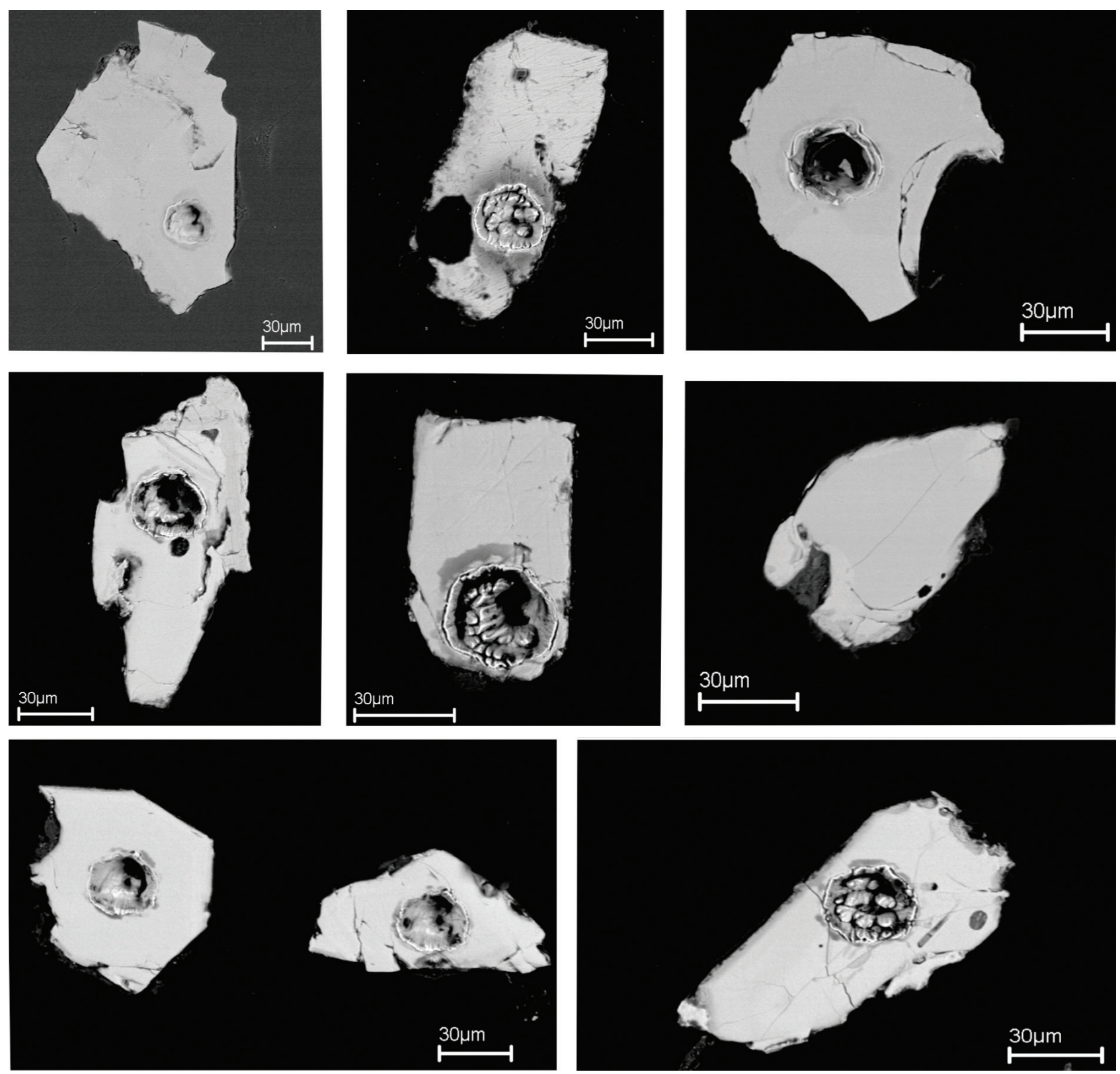

Figure 16 - Backscattered electron images of zircon crystals with position of analysis by Laser Ablation Inductively Coupled Plasma Mass Spectrometry. 


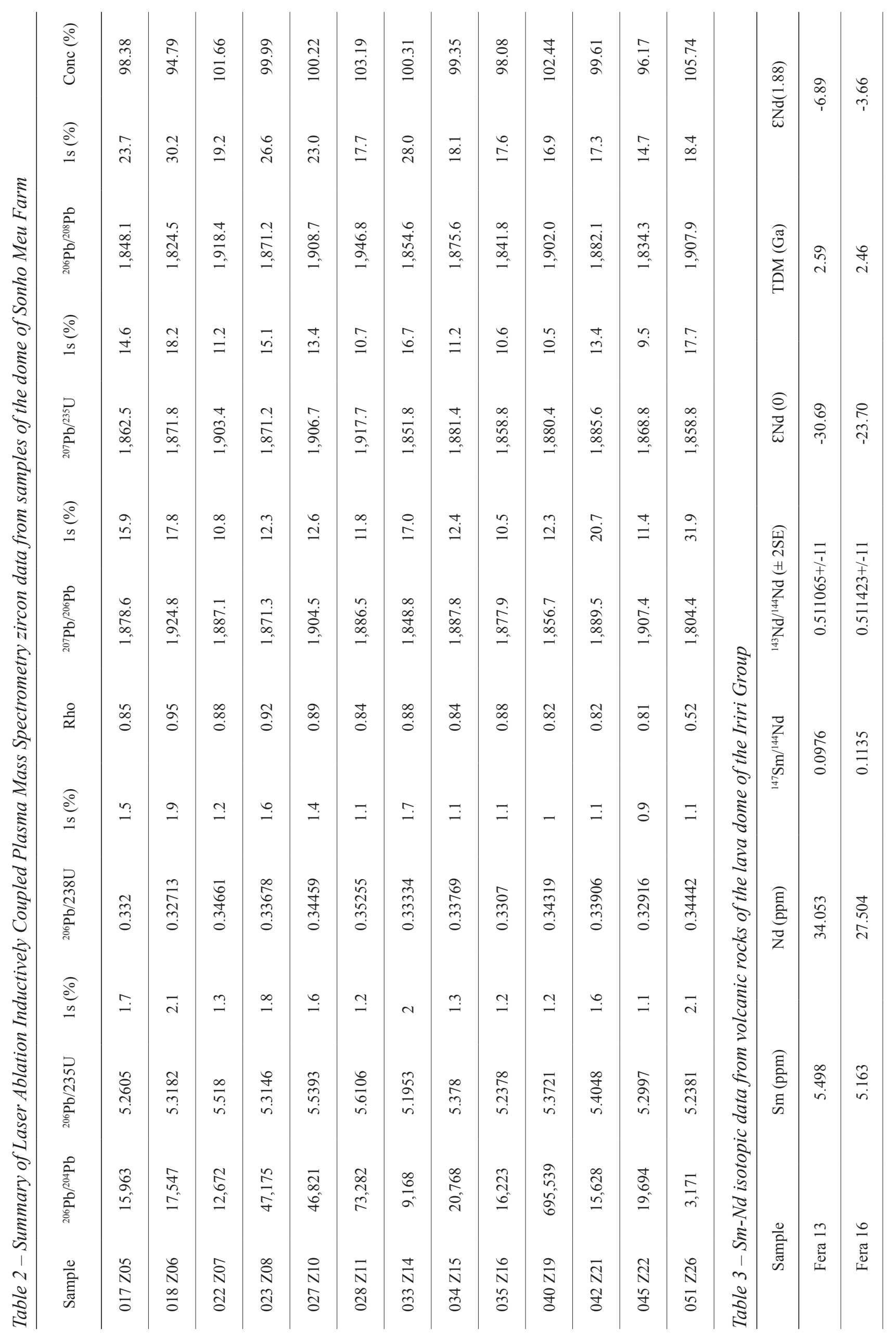




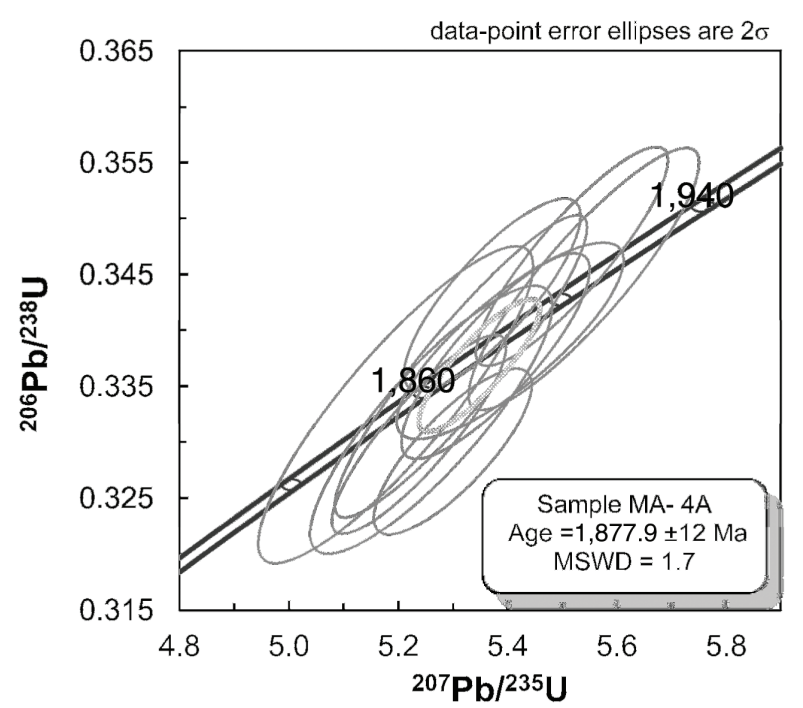

Figure $17-U-P b$ concordia diagram for zircon from sample $M A-4 B$ of the lava dome, showing age of $1,878 \pm 12 \mathrm{Ma}$.

values (-3.66 to -6.89$)$, in addition to the facies of heterogeneous mixture of magmas identified in the field work and examined in details in the petrographic study, are strong evidence that the Lava Dome of Sonho Meu Farm was formed from a mixture of magmas, which were produced mainly by melting mantle source, and subordinately by melting the crustal one.

This paper suggested that the petrogenetic evolution of these magmas is related to the melting of the lithospheric mantle previously modified by subduction processes followed by mineral fractionation. Distensive processes (rift) may have caused the adiabatic decompression and magma ascension to the crust base, supplying the required heat for crustal assimilation and/or melting.
These processes may have contributed to the magma mixture, as indicated by the presence of mafic enclaves associated with the core facies of the lava dome, which indicates that the mixture process that usually occurs in the deep magma chamber continued to shallower levels.

The geochemical and isotope data support a post-collisional tectonic environment for the generation of Iriri Group rocks. The negative Ta-Nb anomaly observed in the multielement diagrams suggests that the source of these rocks was modified by previous subduction processes.

Based on these data, on the zircon U-Pb age of $1.87 \mathrm{Ga}$, on the intermediate to acid composition, and on the geochemical affinity of these rocks, it was possible to establish a relationship between these rocks and those of the Iricoumé Group that with the Iriri Group forms the Uatumã Volcanic Province.

ACKNOWLEDGEMENTS The authors would like to thank: Geociam (Instituto de Geologia da Amazônia) and the Brazilian National Counsel of Technological and Scientific Development (CNPq), under grant numbers 552880/2009-4 and 303038/20098; the post-graduate Program in Geosciences of the Universidade Federal de Mato Grosso (UFMT); the Geochronology Laboratory of the Universidade de Brasília (UnB), as well as professors Hilton Costi and Cláudio Lamarão of the Emilio Goeldi Museum of the Universidade Federal do Pará (UFPA). Special thanks to professor Ronaldo Pierosan for reviewing the manuscript after some corrections suggested by anonymous reviewers had been made.

\section{References}

Alves C.L., Sabóia A.M., Martins E.G., Stropper J.L. (orgs.) 2010. Geologia e Recursos Minerais das Folhas São José do Xingu SC.22-Y-A e Rio Comandante Fontoura SC.22Y-B. CPRM/SICME-MT, Goiânia, escala 1:250.000.120 p.

Amaral G. 1974. Geologia pré-cambriana da região Amazônica. Dissertação de Livre-Docência, Instituto de Geociências, Universidade de São Paulo, São Paulo, 300 p.

Barros M.A.S., Rubert R.R, Padilha R.A., Pimentel M.M., Silva G.D. 2006. Dados Preliminares sobre o plutono vulcanismo do Nordeste de Mato Grosso. In: Fernandes C.J. \& Viana R.R. Coletânea Geológica de Mato Grosso, Mato Grosso, 1, p. 131-147.

Barros M.A.S., Pimentel M.M., Dantas E.L., Padilha R.A. 2008. Geoquímica e dados isotópicos da Suíte Intrusiva Vila Rica e Suíte Intrusiva Rio Dourado - Mato Grosso, área Xingú - Província Amazônia Central - Sul do Cráton Amazônico. In: IV Simpósio de vulcanismo e ambientes associados, Anais..., Foz do Iguaçu, Paraná.
Barros M.A.S., Pimentel M.M., Dantas E., Moura E., Prado E.S., Souza Neto J. 2009. Ocorrências de Formações Ferríferas e de Manganês na Formação Gorotire nas Proximidades do Município de Confresa - Nordeste de Mato Grosso. In: Anais do XI Simpósio de Geologia do Centro-Oeste, Anais..., Cuiabá, Mato Grosso.

Barros M.A.S., Pimentel M.M., Rocha M.L.B.P., Silva F.R., Padilha R.A., Dantas F.R., Moura E. 2011. A Suíte Intrusiva Rio Dourado - Um granito tipo A de 1,88 GaSudeste do Craton Amazônico - Mato Grosso - Brasil. Geologia USP, Série Cientifica, 11(1):75-93.

Basei M. 1977. Idade do vulcanismo ácido a intermediário na região amazônica. Dissertação de Mestrado, Instituto de Geociências, Universidade de São Paulo, São Paulo, 133 p.

Dall'agnol R., Bettencourt J.S., Jorge João X.S., Medeiros H., Costi H.T., Macambira M.J.B. 1987. Granitogenesis in the northern Brazilian region: a review. Revista Brasileira de Geociências, 17(4):382-403. 
Dall'Agnol R., Lafon J.M., Macambira M.J.B. 1994. Proterozoic anorogenic magmatism in the Central Amazonian Province, Amazonian Craton: geochronological, petrological and geochemical aspects. Mineralogy and Petrology, 50:113-138.

Dall'Agnoll R., Ramo O., Magalhães M.S., Macambira M.J.B. 1999. Petrology of the Anorogenic Oxidized Jamon and Musa Granites, Amazonian Craton: Implications for the Genesis of the Proterozoic A Type Granites. Lithos, 46(3):431-462.

De La Roche H., Leterrier J., Grandclaud P., Marchal M. 1980. A classification of volcanic and plutonic rocks using R1-R2 diagrams and major elements analysis its relationships with current nomenclature. Chemical Geology, 29:183-210.

Jackson S.E., Pearsona N.J., Griffina W.L., Belousova E.A. 2004. The application of Laser ablation-inductively coupled plasma-mass spectrometry to in situ U-Pb zircon geochronology. Chemical Geology, 211:47-69.

Lacerda Filho J.V., Abreu Filho W., Valente C.R., Oliveira C.C, Albuquerque M.C. 2004. Geologia e Recursos Minerais do Estado de Mato Grosso. Goiânia. CPRM. CD-ROM, escala 1:1.000.000.

Le Bas M.J., Le Maitre R.W., Streckeisen A., Zanettin B. 1986. A classification of volcanic rocks based on the total alcalissilica diagram. Journal of Petrology, 27:745-750.

Le Maitre R.W. 1989. A Classification of Igneous Rocks and Glossary of Terms: Recommendations of the International Union of Geological Sciences Subcommission on the systematics of igneous rocks. Blackwell, Oxford, 193 p.

Leite J.A.D., Saes G.S., Macambira M.J.B. 2001. The Teles Pires Volcanic Province: A Paleoproterozoic silicic-dominated large igneous province in southwest Amazon Craton and tectonic implications. In: Simpósio sobre vulcanismo e ambientes associados, 1, Boletim de resumos, $93 \mathrm{p}$.

Manley C.H. 1996. In situ formation of welded tuff-like textures in the carapace of a voluminous silicic lava flow, Owyhee County, SW Idaho. Bull Volcanoll, 57:672-686.

McPhie J., Doyle M., Allen R. 1993. Volcanic Textures: A guide to the interpretation of textures in volcanic rocks. CODES Key Centre, Tasmania, $191 \mathrm{p}$.

Maniar P.D. \& Piccoli P.M. 1989. Tectonic Discrimination of granitoids. Geological Society of America Bulletin, 101:635-643.

Padilha R.A. 2007. Petrologia e Geoquímica dos granitos da Suite Intrusiva Vila Rica e do Granito Rio DouradoBorda Sudeste do Cráton Amazônico (Província Amazônia Central - Área Xingu-Iricoumé - Nordeste de Mato Grosso). Dissertação de Mestrado, Instituto de Ciências Exatas e da Terra, Universidade Federal de Mato Grosso, Cuiabá, 120 p.

Padilha R.A. \& Barros M.A.S. 2008. Petrologia e geoquímica das Suítes Intrusivas Vila Rica e Rio Dourado - Província Amazônia Central, borda sudeste do Cráton Amazônico (MT). Revista Brasileira de Geociências, 38(4):642-653.

Patchett P.J. \& Ruiz J. 1987. Nd isotopic ages of crust formation and metamorphism in the Precambrian of eastern and southern Mexico. Contribution of Mineral and Petrology, 96:523-528.

Pearce, J. A., Harris N. B. W., Tindle A. G. 1984. Trace discrimination diagrams for the Tectonics Interpretation of granitic rocks. Contributions to Mineralogy and Petrology, 69:33-47.

Pearce J.A. 1996. Source and settings of granitic rocks. Episodes, 19:120-125.

Pearce J.A., Harris N.B.W., Tindle A.G. 1984. Trace discrimination diagrams for the Tectonics Interpretation of granitic rocks. Contributions to Mineralogy and Petrology, 69:33-47.

Peccerillo A. \& Taylor S.R., 1976. Geochemistry of Eocene calcalkaline volcanic rocks from the Kastamanu Area, Northern Turkey. Contributions to Mineralogy and Petrology, 58:63-81.

Pinho F.E.C., Pinho M.A.S.B., Pimentel M., Souza D.G., Ribeiro J.N., Silva M.A.P., Berlandi R.A., Santos A.A., Cabral C. 2003. Reconhecimento geológico e geocronológico do Cráton Amazônico na região nordeste de Mato Grosso. In: Simpósio de Geologia do CentroOeste - Geologia Desenvolvimento Sustentável, 08. Cuiabá, Boletim de Resumos, p. 90-92.

Pinho M.A.S.B., Rubert R.R., Silva G.D., Chemale Jr., F., Dussin I.A., Costa E.C. 2004. Dados Petrográficos, Geoquímicos e idades U-Pb da vulcânica félsica do Grupo Iriri na porção nordeste de Mato Grosso - Serra dos Magalhães. In: Anais do $42^{\circ}$ Congresso Brasileiro de Geologia, 42, Araxá.

Santos J.O.S., Hartmann L.A., Gaudette H.E., Groves D.I., Mcnaughton N.J., Fletcher I.R.A. 2000. A New Understanding of the Provinces of the Amazon Cráton based on Integration of Field Mapping and U-Pb and SmNd Geochronology. Gondwana Research, 3(4):453-488.

Santos J.O.S., Hartmann L.A., Faria M.S., Riker S.R., Souza M.M., Almeida M.E., McNaughton N.J. 2006. A compartimentação do Craton Amazônico em províncias: avanços ocorridos no período de 20002006. In: Simpósio de Geologia da Amazônia, 9, Seção Temática III, Anais..., Belém, Pará. CD-ROM.

Sun S.S. \& McDonough W.E. 1989. Chemical and isotopic systematic of oceanic basalt: implications for mantle composition and processes. In: Saunders A.D. \& Norry M.J. (eds.). Magmatism in the Ocean Basins: Geological Society Special Publication, 42:313-345.

Tassinari C.C.G. \& Macambira M.J.B. 1999. Geochronological provinces of the Amazonian Cráton. Episodes, 22(3):174-182.

Tassinari C.C.G. \& Macambira M.J. 2004. A evolução tectônica do Craton Amazônico. In: Manteso-Neto V., Bartorelli A., Carneiro C.D.R., Brito Neves B.B. (Orgs.). Geologia do Continente Sul-Americano: evolução e obra de Fernando Flávio Marques de Almeida. São Paulo. Beca, Cap. 28, p. 471-485.

Manuscrito ID 20813

Recebido em: 17/02/2011

Aprovado em: 23/04/2012 